University of Rhode Island

DigitalCommons@URI

Open Access Master's Theses

1990

\title{
The Influence of Area and Habitat on the Avian Community in Red Maple Swamps of Southern Rhode Island
}

Jed S. Merrow

University of Rhode Island

Follow this and additional works at: https://digitalcommons.uri.edu/theses

\section{Recommended Citation}

Merrow, Jed S., "The Influence of Area and Habitat on the Avian Community in Red Maple Swamps of Southern Rhode Island" (1990). Open Access Master's Theses. Paper 1151.

https://digitalcommons.uri.edu/theses/1151

This Thesis is brought to you for free and open access by DigitalCommons@URI. It has been accepted for inclusion in Open Access Master's Theses by an authorized administrator of DigitalCommons@URI. For more information, please contact digitalcommons-group@uri.edu. 
THE INFLUENCE OF AREA AND HABITAT ON

\section{THE AVIAN COMMUNITY IN RED MAPLE SWAMPS OF SOUTHERN RHODE ISLAND}

BY

JED S. MERROW

A THESIS SUBMITTED IN PARTIAL FULFILLMENT OF THE REQUIREMENTS FOR THE DEGREE OF

MASTER OF SCIENCE

IN

NATURAL RESOURCES

UNIVERSITY OF RHODE ISLAND 


\section{MASTER OF SCIENCE THESIS}

OF

JED S. MERROW

\section{APPROVED :}

Thesis Committee

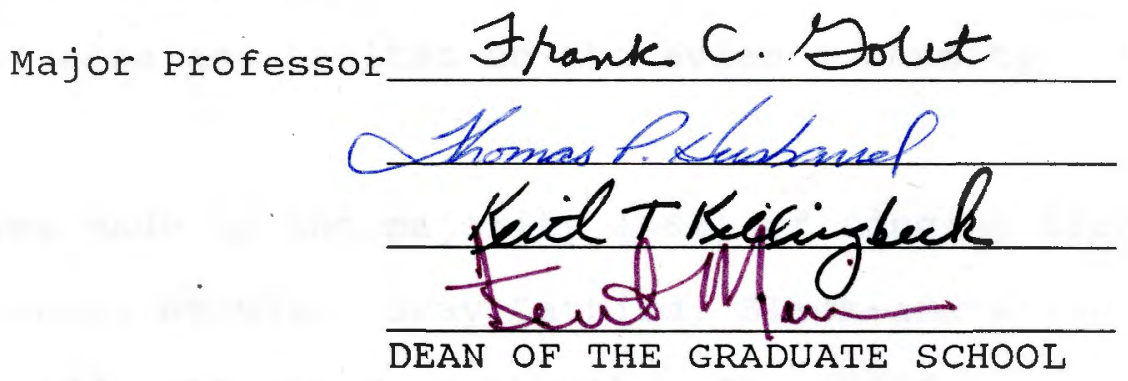

UNIVERSITY OF RHODE ISLAND 


\section{ABSTRACT}

Red maple swamps are common throughout the glaciated Northeast and, along with other wetland types, are protected for their wildlife habitat and other functions. Yet there are few descriptions of red maple swamp wildlife communities, and little research on how the wildlife are influenced by habitat features. Several states define jurisdictional wetlands on the basis of wetland size, but the influence of area on wetland wildlife communities is largely unknown.

Birds were censused in 12 mature, very poorly drained red maple swamps in southern Rhode Island. Swamps ranged from 0.49 to 19.24 ha and were placed in four size categories. Avian community composition was described and the influence of area and habitat on the avian community were examined.

Five species made up the majority (66\%) of singing bird observations: Canada Warbler, Gray Catbird, Black-and-white Warbler, Veery, and Northern Waterthrush. The avian association was similar in composition to that observed by other researchers in red maple swamps in west-central Massachusetts.

Species richness at individual sites ranged from 3 to 15 singing bird species and from 7 to 24 total species. Richness was strongly $(P<0.0001)$ related to swamp area: for 
singing birds, $\mathrm{R}^{2}=0.81$, and for all species observed, $\mathrm{R}^{2}=0.84$. Wetlands in either of the two larger size categories supported significantly more species than wetlands in either of the two smaller categories. Area did not relate significantly to avian relative abundance. The smallest swamps studied, down to 0.5 ha, supported several breeding species, including the Northern Waterthrush, an obligate wetland species. Thus red maple swamps down to at least 0.5 ha have significant wildlife habitat value and support "wetland species." There was a rapid increase in the number of species in swamps up to about 6-8 ha in size, and a slower increase in species richness beyond this size.

In stepwise regression models, swamp area and measures of shrub structure were significantly related to species richness. Avian relative abundance was significantly related only to the thickness of the organic soil layer; the nature of the relationship between these variables is unknown. 


\section{ACKNOWLEDGEMENTS}

I thank first and foremost my major professor, Dr. Frank Golet; for his selfless devotion of his time and energy to this thesis project. His high standards have certainly greatly improved the quality of this document and his student's skills.

There are many others who contributed a great deal to my work. Katie's seemingly boundless patience and understanding are beyond mere thanks. Aram Calhoun's cheerful assistance in adverse conditions was wonderful. And William DeRagon's constant help, expert advice, and friendship have been invaluable.

I also thank Tom Husband and Keith Killingbeck for their careful, thoughtful review and comments; Carol Baker for maps and moral support; Sarah Allen for all of her help; Pete August for being Pete August (keep it up); and Bill Wright for all of his assistance (and assistantships).

The landowners of my study sites were always supportive. I thank Edith Townsend, Irving Taylor, the Samsons, Lucy Tootell, the Kenyons, Mike Sullivan, Sandra Stewart, the Decoppet Estate trustees, the state Division of Fish and Wildlife, and the U.S. Fish and Wildlife service.

Finally, I thank my parents for encouraging me to explore and to learn, and for their unflagging support over the years. 


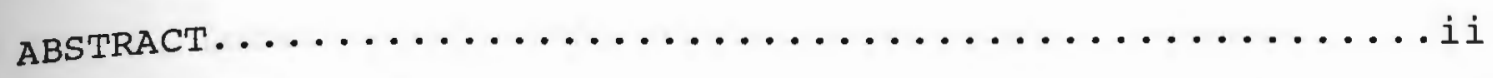

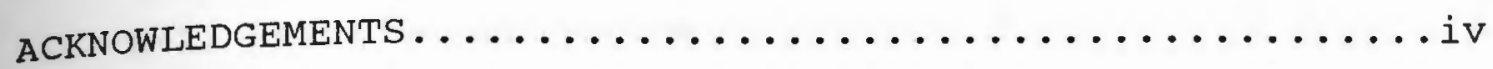

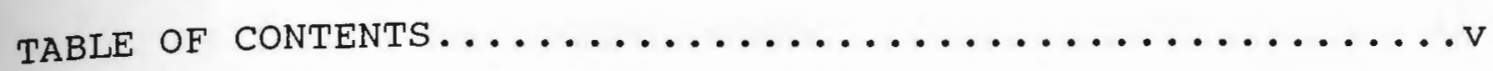

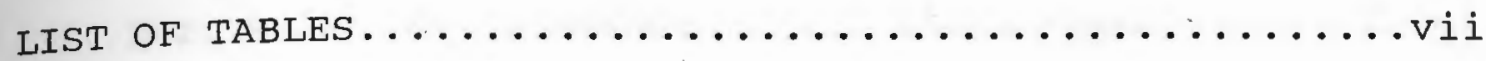

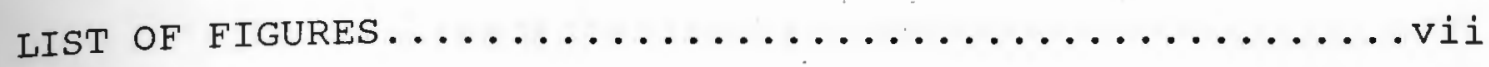

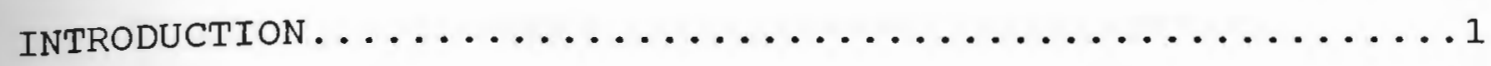
METHODS

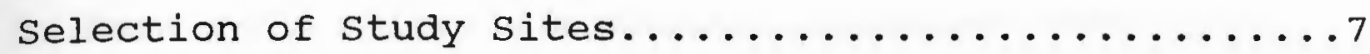

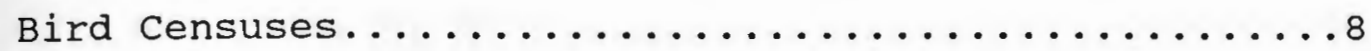

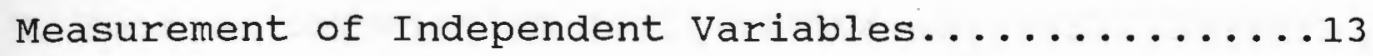

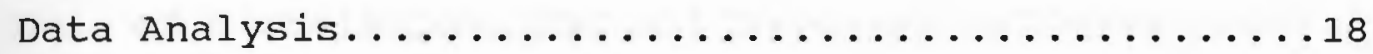
RESULTS AND DISCUSSION

Characteristics of the Avian Community..........20

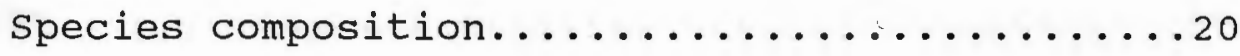

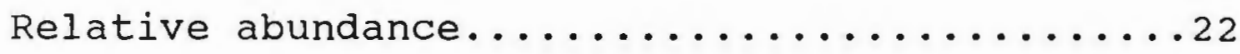

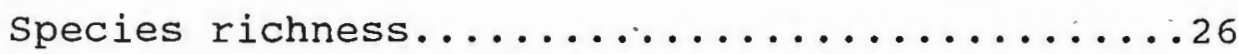

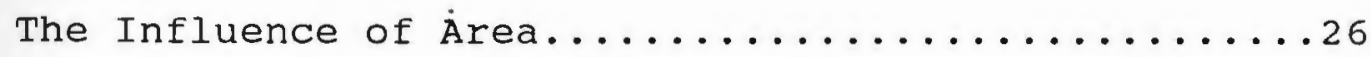

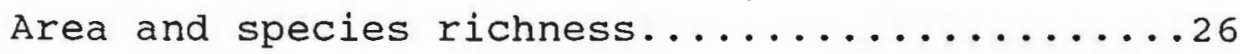
Area and relative abundance.................... 3 Implications for wetland protection and

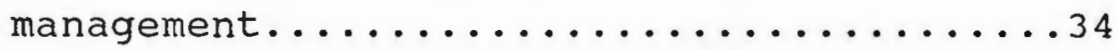

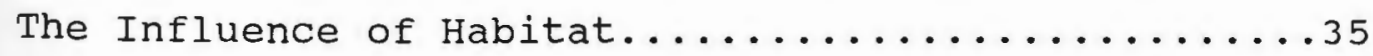

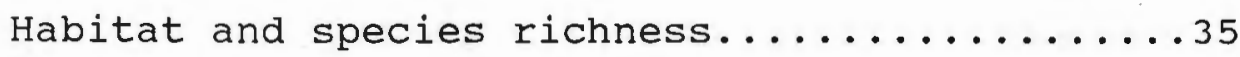
Habitat and relative abundance................... 
IITERATURE CITED.

APPENDICES :

A. Location of study sites.............. 46

$\mathrm{B}-1$. Relative abundance of singing birds in 12 Rhode

Island red maple swamps.............47

$\mathrm{B}-2$. Relative abundance of all birds observed in 12

Rhode Island red maple swamps...........48

c. Common and scientific names of bird species

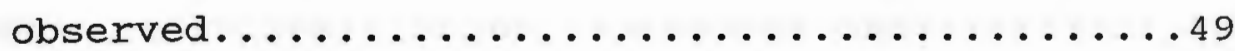

D. Mean values for independent variables used in analyses, by site.....................

E. Pearson correlation coefficients and significance of correlations for all pairs of variables used in analyses.........................

F. Variable codes...................... 53

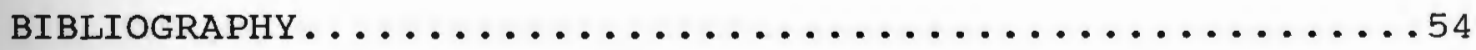




\section{LIST OF TABLES}

Table

Page

1. Area of study sites, number of census plots, and area sampled within each site..................

2. Bird community and independent variables measured...15

3. Birds observed in 12 Rhode Island red maple swamps..21

4. Comparison of the most abundant birds in red maple swamps in southern Rhode Island and west-central

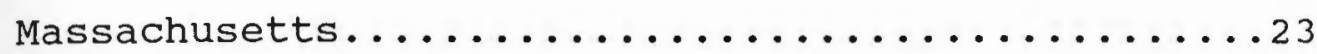

5. Species richness and relative abundance of birds in



6. Average bird species richness and relative abundance for four size categories of red maple swamps.....29 7. Summary of stepwise regression analysis.........36

8. Stepwise regression models.................... 37 


\section{LIST OF FIGURES}

Figure

Page

1. Location of study sites in southern Rhode Island....9

2. Bird species richness in 12 Rhode Island red maple swamps as a function of swamp area............

3. Species richness of singing birds in red maple swamps of southern New England as a function of swamp

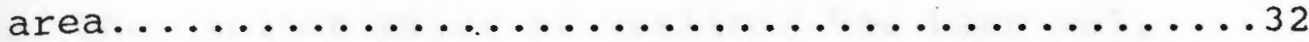




\section{INTRODUCTION}

Wetlands are common throughout the Northeastern United states and are considered one of the most valuable components of the landscape. The role of wetlands as valuable wildife habitat is widely acknowledged and is frequently cited in wetlands protection legislation (e.g., Connecticut, Massachusetts, New York, New Jersey, Rhode Island). The habitat value of wetlands has been well documented in studies of certain habitat types (e.g., marshes) and certain species (principally waterfowl and furbearing mammals; Weller 1979). In other wetland types, including some of the most common types, there has been little research.

Red maple (Acer rubrum) swamp is the most abundant inland wetland type throughout most of the glaciated Northeast (Golet et al., in prep.). In Rhode Island, for example, there are nearly 18,000 ha of broad-leaved deciduous forested wetland (Tiner 1989), comprising $77 \%$ of the inland wetland area in the state and over $6 \%$ of the state's total land area; virtually all of this wetland is dominated by red maple. Despite the prevalence of red maple swamps, there has been little research on their fauna. Knowledge of faunal community composition and the key factors affecting the nature of this community is critical to the proper management of wetlands, including the 
maintenance of viable wildlife populations, the protection of wetland-dependent species, and the assessment of potential impacts of human activities on wetland wildlife. The avian community of red maple swamps has been described at only a few sites in the Northeast. Breeding Bird Census (BBC) results have been reported for three red máple swamps in New Jersey (Black and Seeley 1953; Seeley 1954, 1955, 1956, 1957, 1966; Meyers et al. 1981; Taylor 1984 ) and one in western New York (Slack et al. 1975). Golet et al. (in prep.) have summarized these results. Anderson and Maxfield (1962) used mist nets to census birds in a red maple-Atlantic white cedar (Chamaecyparis thyoides) swamp in southeastern Massachusetts as part of an encephalitis research project. Mist-netting samples a relatively small segment of the bird community and the results are comparable only to studies using similar netting techniques and sampling effort (Karr 1981). Swift et al. (1984) censused the breeding birds in eight large (30-45 ha) west-central Massachusetts red maple swamps. Their study sites were heterogeneous, including both forested swamp and shrub swamp, and both poorly drained and very poorly drained soils (see Wright and Sautter [1988] for drainage class definitions). Some of the sites also included features such as upland islands and powerline corridors.

Clearly, more studies are needed before the avian community of Northeastern red maple swamps can be 
characterized definitively. Further, the effect of variations in geography, plant community structure and floristics, water regime, and other factors should be examined.

Many aspects of habitat influence the density or species richness of forest-dwelling breeding birds. Among these features are the relative length of habitat edge (Kroodsma 1984, Gotfryd and Hansell 1986); the types or diversity of surrounding habitat (Whitcomb et al. 1981, Gotfryd and Hansell 1986); the degree of isolation of the habitat patch from similar habitats (Lynch and Whigham 1984, Opdam et al. 1985); vegetation structure (MacArthur and MacArthur 1961, James and Wamer 1982); and the extent of surface water (Swift et al. 1984).

Only Swift et al. (1984) have investigated the effect of habitat on the avifauna of red maple swamps. Using multiple regression models, they found that the abundance of breeding birds was positively related to the stem density of shrubs 1-3 m tall, the percent cover of surface water, and the depth (thickness) of the organic soil layer. Bird species richness within census plots was positively related to stem density of shrubs 1-3 $\mathrm{m}$ tall and organic soil depth; it was negatively related to tall (3-5 m) shrub stem density and to lowest overstory branch height. As Swift et al. pointed out, however, there was extreme collinearity among their independent variables; this makes it difficult to 
1dentify the most important variables in their regression models. The heterogeneity of their sites further complicates interpretation of the results. Additional research is needed to clarify how variables such as vegetation structure, surface water cover, and organic soil depth influence the avian community in red maple swamps. Several states with legislation regulating wetland alteration protect only wetlands above a certain size. The minimum size of forested wetlands falling under the state's jurisdiction is 1.2 ha in Rhode Island (R.I.G.L., sections 2-1-18 et seq.), 5 ha in New York (N.Y. Environmental Conservation Law, T. 3 of Art. 24), and 4 ha in Maine (widoff 1988). However, it is not clear that the wildlife value of wetlands is a function of wetland size.

The area of a habitat patch strongly affects wildlife community composition (Lack 1942, Gottfried 1979, Lynch and Whigham 1984, King 1987). Larger blocks of habitat tend to support more species in greater numbers (Preston 1960, 1962; MacArthur and Wilson 1967; Simberloff 1972), provide a buffer against the influence of external factors such as parasitic edge species (Martin 1988), and reduce the rate of species extinction within a given patch (Simberloff 1976). On the other hand, several small habitat islands may collectively support more species than a single large island of equal size (MacArthur and Wilson 1967, Simberloff and Abele 1982). Clearly, the relationship between area and 
wildife community composition may have important implications for wildlife conservation and management.

Significant avian species-area relationships have been found in forested habitats (e.g., Opdam et al. 1985, Gotfryd and Hansell 1986, Martin 1988) and in freshwater marshes (Brown and Dinsmore 1986, Tyser 1983). However, no speciesarea research has been done in forested wetlands.

Breeding bird density has been found to decrease as the area of an island or habitat patch increases (Oelke 1966, Martin 1980, Lynch and Whigham 1984). Peitzmeier (1950) proposed four rules on breeding bird density in woodland habitat, including a rule that density decreases as the area of uniform habitat increases. Oelke (1966) reviewed European Breeding Bird Census data and found that "small and moist" areas had higher breeding bird density than larger, drier ones. Linehan et al. (1967) studied 1- to 14-ha forest patches in Delaware and, although he found no clear relationship between area and density, he asserted that the densities found were higher than those from "interior" habitats (i.e., areas removed from habitat edges). Martin (1980) found a highly significant $(P<0.001)$ decrease in density with increasing area of shelterbelts in the U.S. Midwest. Lynch and Whigham (1984) studied a wide range of forest patch sizes in the U.S. Middle Atlantic States, and found patch area to be inversely related to the relative abundance of birds (the total number of pairs of birds 
censused at a single point within each forest).

The influence of wetland size on the abundance and species richness of the avifauna of red maple swamps is unknown; investigation of that topic should provide some basis for judging whether the current size minima of wetland regulations are warranted.

The research reported on here addresses several of the above topics. Specific objectives of this research were:

1. To describe the breeding bird community of mature, very poorly drained red maple swamps, which predominate in much of southern New England. 2. To determine the influence of wetland size on the breeding bird community of these swamps. 3. To further elucidate the influence of habitat on breeding bird abundance and richness in red maple swamps. 


\section{METHODS}

\section{selection of study sites}

Twelve red maple swamps in southern Rhode Island were selected for study. The criteria used in site selection, in approximate order of importance, were:

1. Size. Sites were selected to obtain a range of wetland sizes with at least three sites in each of four size categories. The minimum wetland size was based on the ability of a site to accommodate at least one 0.28 -ha circular census plot.

2. Vegetation. Sites had to be mature wetland forests dominated by red maple, with at least $60 \%$ canopy cover throughout, and without any evidence of significant disturbance. In actuality, canopy cover exceeded $68 \%$ at every census plot and averaged over $80 \%$ for every site selected.

3. Soil drainage class. All sites had to have predominantly very poorly drained soils; the boundary between very poorly drained and drier soils was defined as the wetland edge.

4. Isolation. The study sites had to be continuous blocks of very poorly drained red maple swamp isolated from other maple swamps by dissimilar habitat. In some places, the study sites were separated from other 
wetlands by only a narrow $(<10 \mathrm{~m})$ strip of upland habitat; in other cases, small patches of other wetland types occurred at the periphery of study wetlands. 5. Surrounding habitat. Surroundings were to be primarily upland deciduous forest.

Potential study sites were identified using the soil Survey of Rhode Island (Rector 1981), wetland maps of the towns of Richmond (Golet and Davis 1982) and South Kingstown (Golet and Parkhurst, Dept. Forest Wildl. Manage., Univ. Rhode Island, Kingston), and National Wetlands Inventory maps (U.S. Fish and Wildlife Service) of southern Rhode Island. Sites meeting the above criteria were examined on large-scale aerial photographs and then field-checked. The sites selected (Figure 1 and Appendix A) ranged from 0.49 ha to 19.24 ha and were grouped in 4 size categories (Table 1).

\section{Bird Censuses}

Censusing birds in wooded swamps presents two major problems. First, the vegetation is dense, so that birds are difficult to see and must be censused primarily by vocalizations. This makes spot-mapping, which depends largely on visual observations, difficult. second, in small swamps, the observer is often close to a habitat edge, so that unlimited-distance methods such as Emlen's variable-width transect (Emlen 1971, 1977) and the Indice 


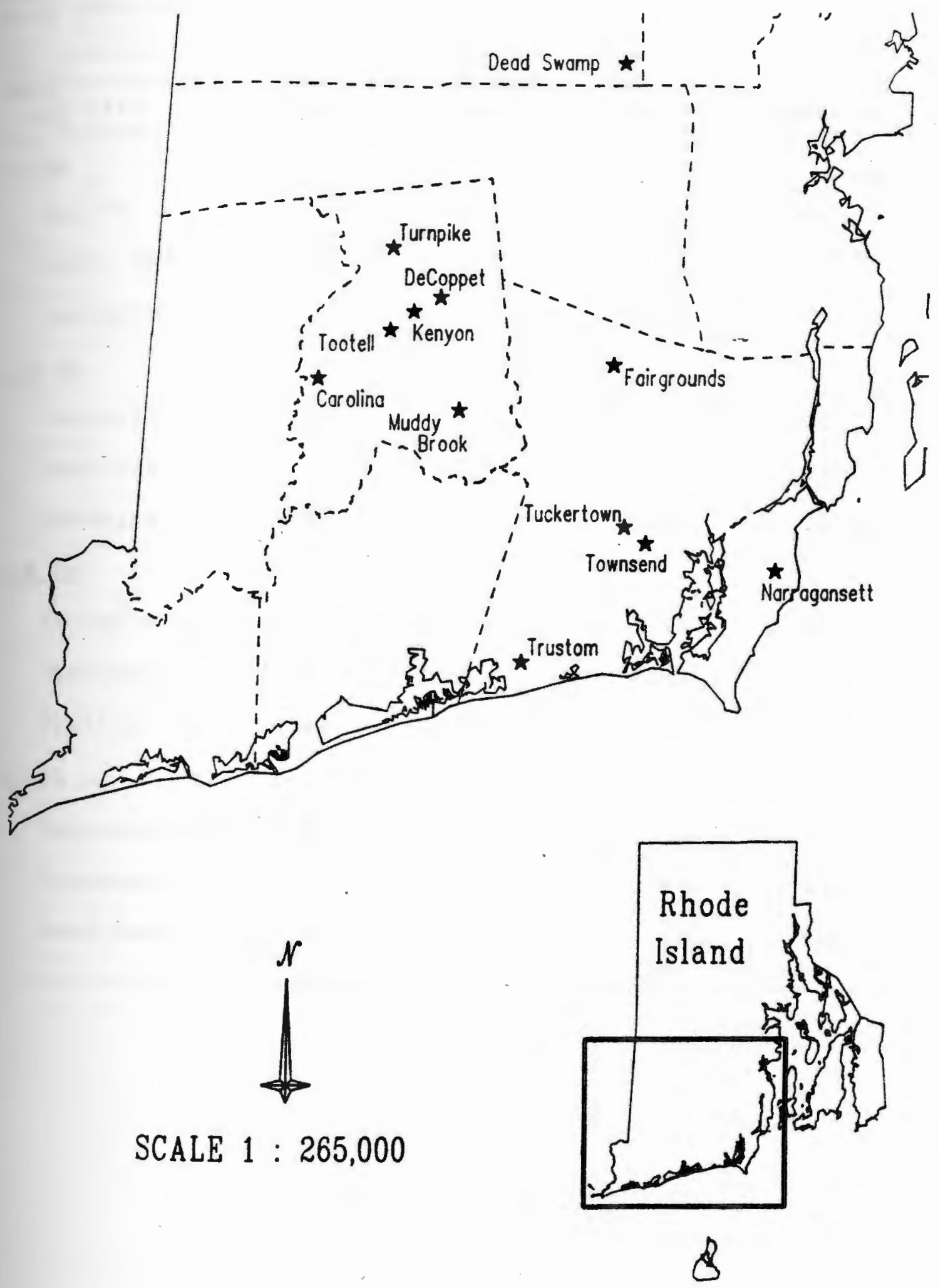

Figure 1. Location of study sites in southern Rhode Island. 
Table 1. Area of study sites, number of census plots, and area sampled within each site.

size category

and site

$\leq 1$ ha

Kenyon

Muddy Brook

Tuckertown

$1-5$ ha

Tootell

Carolina

Turnpike

6-8 ha

Fairgrounds

6.17

5

5

6

7.43

13-20 ha

Narragansett 13.21

13.49

19.24

Dead Swamp

Townsend

19.24

10

14
Sampled $\%$ of site area (ha) sampled 
ponctuel D'Abondance (IPA) point count (Blondel et al. 1981) are inappropriate. For these reasons, the fixed-radius circular plot technique was selected (Edwards et al. 1981, Swift et al. 1984, Degraaf 1987, Morrison et al. 1987). This method is relatively simple, but requires that the observer accurately judge the location of singing birds with respect to plot boundaries. Most sources of error for this approach (such as the accuracy of distance estimates or variable weather conditions) also affect other census methods.

Censuses were carried out in $30-\mathrm{m}$ radius $(0.28-\mathrm{ha})$ circular plots located at the nodes of a 90-m grid established in each study area. A transparent representation of the grid was placed randomly over aerial photographs of the study sites, and then the grid was established in the field. All plots falling wholly within site boundaries were selected for sampling. To ensure that at least $20 \%$ of each site's area was sampled, a small number of plots which intersected the wetland edge were repositioned to lie entirely within the site. Plots were relocated following strict guidelines to ensure that (1) the minimum spacing of $30 \mathrm{~m}$ between plot edges was preserved, and (2) the randomness of plot placement was maintained insofar as possible. The number of plots within each site, the total area sampled, and the percentage of each site sampled are listed in Table 1. 
Birds were censused six times at each plot center between 25 May and 2 July 1988. Each plot census consisted of a 1-min "settling" period followed by a 5-min observation period during which all bird observations within the plot were recorded. The bird species and type of observation--singing, calling, or visual--were noted. Only clearly identifiable territorial or mate-attraction vocalizations that are frequently repeated by birds on territories were considered "songs." All censuses were carried out within 4 hours after sunrise.

Each morning one group of sites was censused. Each group consisted of two or three sites. Groups were fixed throughout the census season and were based on site size categories and proximity: sites within a group were from different size categories and were as far apart geographically as feasible. The order of censusing of groups, sites within a group, and plots within a site was varied in the following systematic way in an effort to minimize the effects of time of day and season.

1. The order in which groups were censused was rotated after each complete round of sites, so that the group that was censused first in a given round was censused last in the following round.

2. The order in which sites within a group were censused was rotated each successive time, as with 
groups.

3. The order of censusing of plots within a site was reversed for each successive census.

Species richness (the total number of species observed during all six censuses) and relative abundance (the average number of birds per plot per census) were calculated for both singing bird observations and all bird observations at each site.

\section{Measurement of Independent Variables}

Measurements of study-site area and surrounding habitat diversity were based on 1:4,800-scale panchromatic aerial photographs. Area measurements were made with a digital planimeter, and the length of wetland edge corresponding to each surrounding habitat type was determined with a map measurer. These edge lengths were then entered into the Shannon diversity formula (Shannon 1948) to obtain a measure of surrounding habitat diversity for each study site. Patches of surrounding habitat had to be within $50 \mathrm{~m}$ of the wetland edge and at least $50 \mathrm{~m}$ long and wide to be measured. Eight categories of habitat types were defined: developed (e.g., residential) land; open upland (<10\% tree canopy cover): sparsely forested upland (10\%-40\% tree canopy cover); open wetland (<40\% canopy cover); and four other types of forest land ( $>40 \%$ cover): deciduous upland forest, 
coniferous upland forest, deciduous wetland forest, and coniferous wetland forest. Wetlands were defined as areas with very poorly drained soil.

Methods for sampling vegetation were adapted from swift et al. (1984). Each census plot contained four 28-m transect lines oriented in the cardinal directions and originating $2 \mathrm{~m}$ from the plot center. Vegetation, surface water cover, and peat depth were sampled along these transects. The minimum acceptable sample size for each variable was determined in pilot studies prior to formal sampling. All variables and methods of measurement are described below and summarized in Table 2 .

1. Tree canopy cover. A densiometer was used to estimate percent canopy cover. Four readings were taken, one $6 \mathrm{~m}$ from the plot center along each transect so that the canopy areas measured were centered over each transect. The total sample covered an estimated $800 \mathrm{~m}^{2}$ or $28 \%$ of each bird census plot.

2. Tree density. The total number of trees, including dead trees (woody plants $>3 \mathrm{~m}$ tall and $>7.6 \mathrm{~cm}$ diameter at breast height $[\mathrm{dbh}]$ ) and live trees (woody plants $>6$ $\mathrm{m}$ tall), was recorded in four $6-\times 28-\mathrm{m}$ belts centered on the line transects.

3. Tree diversity. Live trees were identified to species, and the Shannon index (Shannon 1948) was used 
Table 2. Bird community and independent variables measured.

\section{nd community Variables}

Species richness (no. species/site)

Relative abundance

(ave. no. individuals/

plot/census)

\section{independent Variables}

Area (ha)

Edge: area

surrounding habitat diversity

Live and dead tree density (stems/ha)

Live and dead tree basal area $\left(\mathrm{m}^{2} / \mathrm{ha}\right)$

Tree species diversity

Tree height (m)

Canopy cover (\%)

Shrub cover (\%)

Herb cover (\%)

Surface water (\%)

Shrub foliage volume (\%)

Depth (thickness) of organic soil layer

(m)
6 censuses in $1-14$ plots/site*

6 censuses
Planimeter on aerial photos

Map measurer on aerial photos

Map measurer; Shannon diversity index

counts in four 6- $x$ 28-m belts/ census plot

DBH tape on counted trees

Live tree data; Shannon

diversity index

Altimeter on 5 trees/plot

Four densiometer readings/plot

Line-intercept (Canfield 1941) on 4 28-m transects/plot

Line-intercept, as for shrubs

Presence/absence at 60 points/plot on 3 dates

Subjective estimation at 56 locations/plot (14/transect)

Probe at 5 points/plot

Tree canopy, total shrub, and herb cover in Shannon index

Foliage height diversity

(0.28-ha area) circular bird * Plot refers
census plot. 
to calculate live tree species diversity.

4. Tree height. The heights of five live trees, one nearest the plot center and one nearest the distal end of each transect (within the plot), were measured with a Haga altimeter.

5. Tree basal area. The diameter at breast height of all live trees within the $6-\times 28-m$ subplots was measured with a diameter tape and later converted to basal area.

6. Shrub cover. Percent cover of shrubs was measured along the four 28-m transect lines, using a modification of the line-intercept method (Canfield 1941). Shrubs were divided into four layers: low shrubs $(>0-0.9 \mathrm{~m})$, medium shrubs $(>1-1.9 \mathrm{~m})$, tall shrubs $(>2-3.9 \mathrm{~m})$, and saplings $(>4-5.9 \mathrm{~m})$. The minimum unit of measurement along the transect line, determined by pilot studies, was $0.5 \mathrm{~m}$. Only the tallest (i.e., dominant) of the four layers was recorded at any point along the line.

7. Shrub foliage volume. Foliage volume was visually estimated for each of the four shrub layers described above. This method adopts the categorical approach found in two-dimensional cover estimators (Daubenmire 1959, Goldsmith et al. 1986), and is similar in concept to other recent efforts to quantify foliage volume in dense habitats (August 1983, Clark et al. 1983). The 
volume of foliage and branches was estimated within three-dimensional, vertically stacked plots along each line transect. The low- and the medium-shrub plots each were $1 \times 1 \times 1 \mathrm{~m}$ in extent, and the tall shrub and sapling plots were $2 \times 1 \times 1 \mathrm{~m}$ each. Foliage volume for each of the four layers was estimated at 2-m intervals (14 locations) along each transect line. As with the Daubenmire (1959) method, the percentage estimates were assigned to one of six categories: $0-5 \%$, 5-25\%, 25-50\%, 50-75\%, 75-95\%, or 95-100\% Statistics were calculated using category midpoints.

8. Herb cover. The percent cover of herbaceous vegetation was estimated, using the line-intercept method with a minimum unit of measurement of $0.5 \mathrm{~m}$, on all four line transects. Herbs were defined as all nonwoody vascular plants over $2 \mathrm{~cm}$ tall.

9. Percent cover of surface water. The percent of the total surface area in each census plot that was covered with standing water was estimated by recording the presence or absence of water at $2-\mathrm{m}$ intervals along each transect (i.e., 60 points/plot). Sampling was conducted at all sites on consecutive rainless days near the beginning, middle, and end of the 6-week bird census period. Results from these three samples were then averaged. 
10. Depth of the organic soil layer. Total depth (thickness) of the organic horizons was measured in each plot by probing the organic layer down to refusal with a $1.25-\mathrm{cm}$ diameter metal rod at five points: at the plot center and $20 \mathrm{~m}$ from the center on each of the four transect lines. The maximum depth of the probe was. $3 \mathrm{~m}$.

11. Foliage height diversity. To obtain a measure of foliage height diversity (MacArthur 1964), the percent cover of three vegetation layers (tree, shrub, and herb) were entered into the Shannon diversity formula.

\section{Data Analysis}

Regression analysis was used to describe the relationship between species richness or bird abundance and swamp area, and analysis of variance was used to determine whether differences between size categories of wetlands were significant. The significance of differences was determined using Duncan's New Multiple Range Test (Dowdy and Wearden 1983). The significance level for all tests was $\mathrm{P}<0.05$ unless otherwise noted.

Stepwise multiple linear regression (Dowdy and Wearden 1983) was used to determine which independent variables explained the most variation in bird species richness and relative abundance. Data collected for each habitat 
variable were averaged across census plots to obtain a single value for each study site; in all of the above statistical analyses, therefore, each site represents one sample. Data from the sapling layer had insufficient information content (there was uniformly low sapling cover at all sites) and were omitted from the analyses. 


\section{RESULTS AND DISCUSSION}

Bharacteristics of the Avian community

pecies composition.--The 62 plots were censused 6 times each, representing a total of 31 hours of census time. over the 6-week census period, 350 singing bird observations, mpresenting 25 species, and 758 bird observations of all kinds (singing and non-singing), totalling 39 species, were recorded. Two-thirds (66\%) of the singing bird observations consisted of 5 species (Table 3): the Canada Warbler (21\% of all singing observations), Gray Catbird (13\%), Black-andwhite Warbler (13\%), Veery (9\%), and Northern Waterthrush $(9 \%)$. Five species made up just over half (53\%) of all bird observations; the Black-capped Chickadee (16\%) was most abundant, followed by the Canada Warbler (12\%), Veery (10\%), Gray Catbird (9\%), and Black-and-white warbler (6\%). The few species making up the majority of observations might be considered the core of a red maple swamp bird association in Rhode Island. The relative abundance of each species within each site is listed in Appendix B.

The Gray catbird was the only species observed singing at every site (Table 3 ). Other common singing birds included the Canada warbler (10 sites), Veery (9), and Black-and-white warbler (8). The results for all bird observations were similar: Gray Catbird (12 sites), Blackcapped Chickadee (11), Veery (11), Canada Warbler (10), and 
Table 3. Birds observed in 12 Rhode Island red maple swamps during the 1988 breeding season.

\begin{tabular}{|c|c|c|c|c|c|c|}
\hline \multirow{3}{*}{ species $^{b}$} & \multicolumn{4}{|c|}{ Total observations } & \multicolumn{2}{|c|}{ No. sites } \\
\hline & \multicolumn{2}{|c|}{ Singing birds } & \multirow{2}{*}{$\frac{\mathrm{All}}{\mathrm{n}}$} & \multirow{2}{*}{$\frac{\mathrm{birds}}{\%}$} & \multirow{2}{*}{$\begin{array}{l}\text { Singing } \\
\text { birds }\end{array}$} & \multirow{2}{*}{$\begin{array}{c}\text { All } \\
\text { birds }\end{array}$} \\
\hline & $n$ & $\%$ & & & & \\
\hline Canada Warbler & 75 & 21.4 & 89 & 11.7 & 10 & 10 \\
\hline Gray Catbird & 46 & 13.1 & 66 & 8.7 & 12 & 12 \\
\hline Black-and-wh. Warbler & 45 & 12.9 & 49 & 6.5 & 8 & 9 \\
\hline Veery & 33 & 9.4 & 75 & 9.9 & 9 & 11 \\
\hline Northern Waterthrush & 32 & 9.1 & 34 & 4.5 & 7 & 7 \\
\hline Common Yellowthroat & 18 & 5.1 & 38 & 5.0 & 7 & 8 \\
\hline Great cres. Flycatcher & 16 & 4.6 & 18 & 2.4 & 7 & 7 \\
\hline Rufous-sided Towhee & 13 & 3.7 & 23 & 3.0 & 3 & 7 \\
\hline Tufted Titmouse & 11 & 3.1 & 45 & 5.9 & 6 & 8 \\
\hline Red-eyed Vireo & 11 & 3.1 & 11 & 1.5 & 7 & 7 \\
\hline American Redstart & 10 & 2.9 & 10 & 1.3 & 2 & 2 \\
\hline Wood Thrush & 4 & 1.1 & 5 & 0.7 & 3 & 3 \\
\hline American Robin & 4 & 1.1 & 26 & 3.4 & 2 & 4 \\
\hline Blue-winged Warbler & 4 & 1.1 & 4 & 0.5 & 3 & 3 \\
\hline Northern oriole & 4 & 1.1 & 10 & 1.3 & 2 & 3 \\
\hline Carolina Wren & 3 & 0.9 & 3 & 0.4 & 2 & 2 \\
\hline House Wren & 3 & 0.9 & 3 & 0.4 & 2 & 2 \\
\hline White-eyed Vireo & 3 & 0.9 & 3 & 0.4 & 2 & 2 \\
\hline Chestnut-sided Warbler & 3 & 0.9 & 3 & 0.4 & 2 & 2 \\
\hline Scarlet Tanager & 3 & 0.9 & 3 & 0.4 & 2 & 2 \\
\hline Rose-breasted Grosbeak & 3 & 0.9 & 5 & 0.7 & 2 & 2 \\
\hline Black-th. Green Warbler & $r 2$ & 0.6 & 2 & 0.3 & 1 & 1 \\
\hline Black-capped Chickadee & 1 & 0.3 & 122 & 16.1 & 1 & 11 \\
\hline Yellow-throated Vireo & 1 & 0.3 & 1 & 0.1 & 1 & 1 \\
\hline Northern Cardinal & 1 & 0.3 & 1 & 0.1 & 1 & 1 \\
\hline Blue Jay & & & 32 & 4.2 & & 6 \\
\hline White-breasted Nuthatch & & & 8 & 1.1 & & 3 \\
\hline Brown Creeper & 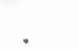 & & 7 & 0.9 & & 5 \\
\hline Hairy Woodpecker & & & 6 & 0.8 & & 2 \\
\hline Northern Flicker & & & 6 & 0.8 & & 3 \\
\hline Song Sparrow & & & 6 & 0.8 & & 1 \\
\hline Blue-gray Gnatcatcher & & & 5 & 0.7 & & 2 \\
\hline Brown-headed cowbird & & & 5 & 0.7 & & 3 \\
\hline Downy woodpecker & & & 4 & 0.5 & & 2 \\
\hline Common Grackle & & & 3 & 0.4 & & 2 \\
\hline Ruffed Grouse & & & 1 & 0.1 & & 1 \\
\hline Eastern Phoebe & & & 1 & 0.1 & & 1 \\
\hline Prairie Warbler & & & 1 & 0.1 & & 1 \\
\hline Ovenbird & & & 1 & 0.1 & & 1 \\
\hline $\begin{array}{l}\text { Unidentified species } \\
\text { All species }\end{array}$ & $\frac{1}{350}$ & 0.3 & $\frac{23}{758}$ & 3.0 & 1 & 10 \\
\hline
\end{tabular}

b Figures are based on 65 -min censuses in 62 plots. Species' scientific names are listed in Appendix $c$. 
Mack-and-white Warbler (9).

The most abundant species generally were found in the greatest number of study sites. Although most species boserved were represented by only a few individuals, many were found at a relatively large number of study sites. Rufous-sided Towhees, Great Crested Flycatchers, and Redeyed vireos each accounted for $3 \%$ or less of all observations, yet were censused at seven sites. Brown creepers were observed only seven times overall ( $1 \%$ of observations), but were found at five study sites.

In eight west-central Massachusetts red maple swamps studied by Swift (1980), the most abundant species were largely the same as those encountered in southern Rhode Island (Table 4). The minor differences may be attributable to differences in habitat complexity or geographic variation in species abundances or habitat use. It is apparent that the avian community of red maple swamps in southern New England is dominated by fewer than 10 common species.

\section{Relative abundance.--Relative abundance}

(birds/plot/census) of singing birds ranged from 0.58 at the Marragansett site to 2.00 at Tuckertown (Table 5), with an average for all study sites of $1.05 \pm 0.11$ (SE). Relative abundance at most study sites ( 9 of 12 ) fell within the relatively narrow range of 0.80 to 1.08 . The relative abundance of all birds observed ranged from 1.58 at carolina 
Table 4. Comparison of the most abundant birds in red maple swamps in southern Rhode Island (this study) and westcentral Massachusetts (Swift 1980).

Southern Rhode Island

Species ${ }^{a}$

Singing birds rank

211

132

133

94

95

56

3. 9

$<1 \quad 23$

o -

75

$\frac{\text { All birds }}{\%^{b} \text { rank }}$

12

94

76

$7 \quad 5$

103

$5 \quad 8$

$7 \quad 5$

$5 \quad 7$

$18 \quad 1$

Tufted Titmouse

Black-capped Chickadee

ovenbird

Total

$\begin{array}{llll}6 & 1 & 3 & 10\end{array}$

$\begin{array}{ll}<1 & 34 \quad 8\end{array}$

68

76
Massachusetts $\frac{\text { Singing birds }}{\%^{b} \text { rank }}$

a Rhode Island figures are based on 65 -min censuses in 62 plots in one year; Massachusetts figures are based on 12 -min censuses in 80 plots over two years.

Percentage of all birds censused in the category (RI) or study (MA). 
Table 5. Species richness and relative abundance of birds in 12 Rhode Island red maple swamps, based on 6 censuses during the 1988 breeding season.

\begin{tabular}{|c|c|c|c|c|}
\hline \multirow[b]{2}{*}{$\begin{array}{l}\text { Size category } \\
\text { and site }\end{array}$} & Species & richness & \multicolumn{2}{|c|}{$\begin{array}{l}\text { Relative abundance } \\
\text { (birds/plot/census) }\end{array}$} \\
\hline & $\begin{array}{l}\text { Singing } \\
\text { birds }\end{array}$ & $\begin{array}{l}\text { Al1 } \\
\text { birds }\end{array}$ & $\begin{array}{l}\text { Singing } \\
\text { birds }\end{array}$ & $\begin{array}{l}\text { Al1 } \\
\text { birds }\end{array}$ \\
\hline \multicolumn{5}{|l|}{$\leq 1 \mathrm{ha}$} \\
\hline Kenyon & 3 & 8 & 1.00 & 2.17 \\
\hline Muddy Brook & 4 & 9 & 1.00 & 2.17 \\
\hline Tuckertown & 6 & 7 & 2.00 & 2.33 \\
\hline \multicolumn{5}{|l|}{$1-5 \mathrm{ha}$} \\
\hline Tootell & 6 & 11 & 1.08 & 1.75 \\
\hline Carolina & 5 & 9 & 0.83 & 1.58 \\
\hline Turnpike & 7 & 11 & 0.83 & 2.11 \\
\hline \multicolumn{5}{|l|}{$6-8 \mathrm{ha}$} \\
\hline Fairgrounds & 8 & 14 & 0.87 & 1.80 \\
\hline DeCoppet & 11 & 17 & 1.67 & 2.77 \\
\hline Trustom & 13 & 18 & 0.94 & 2.03 \\
\hline \multicolumn{5}{|l|}{$13-20 \mathrm{ha}$} \\
\hline Narragansett & 11 & 15 & 0.58 & 1.68 \\
\hline Townsend & 15 & 20 & 0.80 & 1.85 \\
\hline Dead Swamp & 15 & 24 & 1.05 & 2.36 \\
\hline
\end{tabular}


to 2.77 at Decoppet, with an overall mean of $2.05 \pm 0.10$. Relative abundance estimates are directly influenced by the length of the census period and the size of the sample plot. This study used 5 -min censuses; the popular Indice ponctuel D'Abondance (IPA) point-count method (Blondel et al. 1981) utilizes 20-min censuses, and many other methods use censuses of unspecified or variable lengths. In each case, the result is an index of abundance which can only be compared to other indices derived in exactly the same manner.

Swift et al. (1984) also conducted six 5-minute censuses each year in roughly quarter-hectare census plots in red maple swamps in west-central Massachusetts. They censused birds in 800.25 -ha plots at 8 sites over 2 years, compared to the 620.28 -ha plots censused at 12 sites in this study. The overall relative abundance reported by Swift et al. (average, 2.79) is about 2.5 times as high as the present study's singing bird relative abundance (1.05) and about a third higher than the all-bird relative abundance $(2.05)$ calculated here.

There are at least two possible explanations for these differences. First, Swift et al. (1984) used a broader definition of "singing" than was used here (B.L. Swift, NY Dept. Environ. Conserv., Albany; pers. comm., 1988), so that more species (for instance, Blue Jays and Brown-headed Cowbirds) were considered "singing" birds, and more kinds of 
vocalizations were considered songs. Second, their study sites were more heterogeneous, often containing upland 1slands, powerline rights-of-way, large canopy openings, and areas of poorly drained soils. More diverse habitat and Increased habitat edge may support a higher density and diversity of birds (Beecher 1940).

Species richness.--Species richness for singing birds ranged from three at Kenyon, the smallest site, to 15 at Townsend and Dead Swamp, the two largest (Table 5). For all birds, richness ranged from seven species at Tuckertown to 24 at Dead Swamp.

\section{The Influence of Area}

Area and species richness.--Regression analysis showed a highly significant relationship $(\mathrm{P}<0.0001)$ between the species richness of both singing birds and all birds and red maple swamp area (Figure 2). Regressions based on logtransformed data explained slightly more of the variation in richness than those based on untransformed data (singing birds, $R^{2}=0.86$ vs. $R^{2}=0.81 ;$ all birds, $R^{2}=0.86$ vs. $R^{2}=0.84$, respectively). The log-log regression equations are:

Singing birds: Log species richness $=0.68+0.38(\log$ area $)$ All birds: Log species richness $=0.95+0.28(\log$ area $)$ 

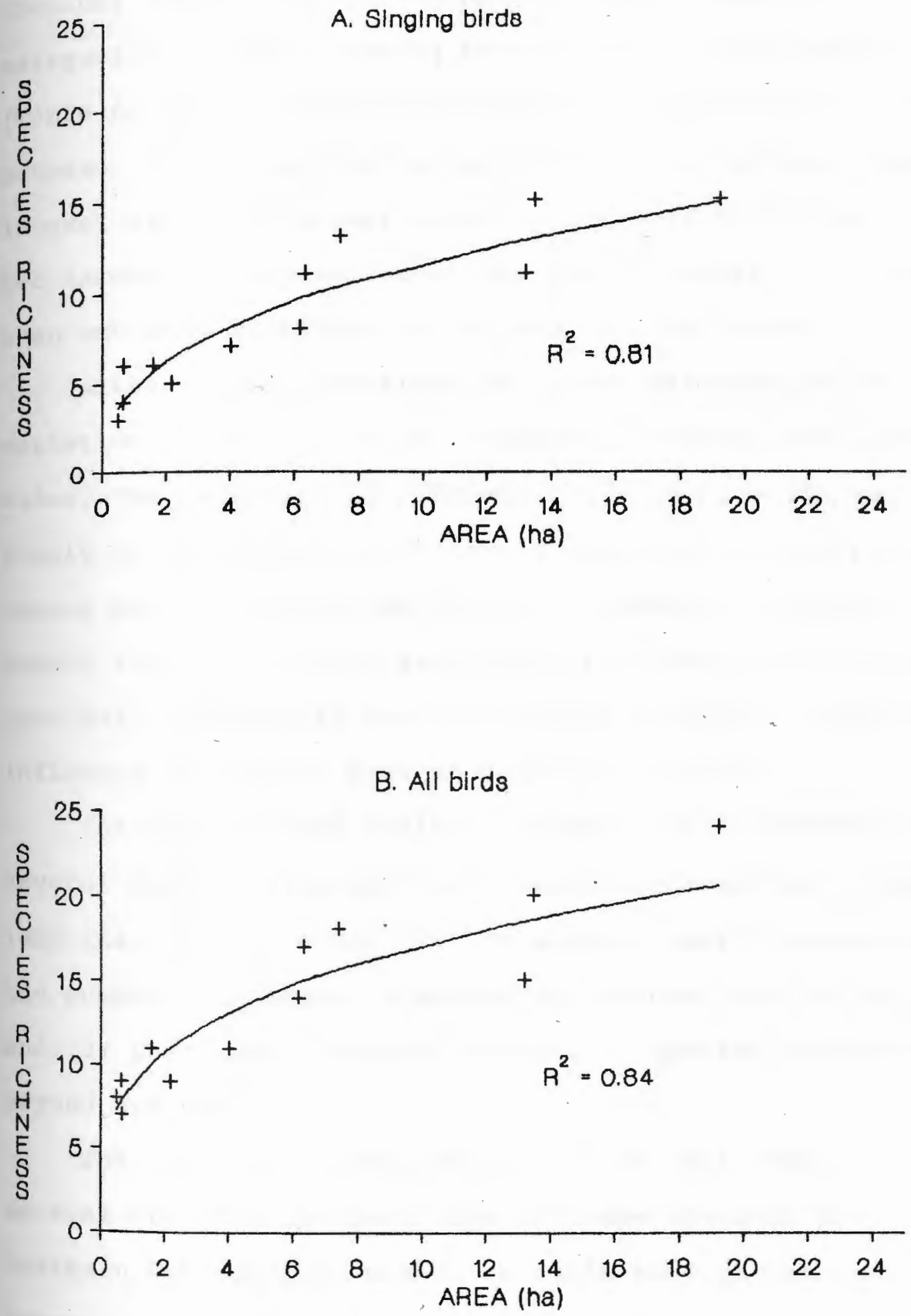

Flgure 2. Bird species richness in 12 Rhode Island red maple swamps as a functlon of swamp area. 
Analysis of variance revealed significant differences $(P<0.05)$ among the mean richness values of wetland size categories for both singing birds and all birds observed (Table 6). Species richness was not significantly different between the two smallest size categories or between the two largest size categories; however, wetlands in either of the two largest categories supported significantly more species than wetlands in either of the two smallest categories. Although area explained the great majority of the variation in the singing bird species richness among study sites, the variation in richness can also be explained simply by the variation in sample area (i.e., number of census plots) among sites $\left(R^{2}=0.77\right)$. However, because sample area and wetland area are very closely correlated $(r=0.99)$, the results are believed to accurately reflect the influence of wetland area on species richness.

The species-area analysis showed that (1) there were several species singing--and presumably breeding--in swamps less than 1 ha in size, (2) there was a rapid increase in the number of species in swamps up to about 6-8 ha in size, and (3) there was a slower increase in species richness beyond 6-8 ha.

The smallest sites, down to $0.5 \mathrm{ha}$, all supported several breeding species. One of these species, the Northern Waterthrush, was an obligate wetland species. Brown and Dinsmore (1986) and Tyser (1983) also found 
Table 6. Average bird species richness and relative abundance for four size categories of red maple swamps based on six censuses during the 1988 breeding season.

\begin{tabular}{|c|c|c|c|c|c|}
\hline \multirow[b]{2}{*}{$\begin{array}{c}\text { size } \\
\text { category }\end{array}$} & \multirow[b]{2}{*}{$\begin{array}{l}\text { No. } \\
\text { sites }\end{array}$} & \multicolumn{2}{|c|}{ Ave. richness } & \multicolumn{2}{|c|}{ Ave. rel. abundan } \\
\hline & & $\begin{array}{c}\text { Singing } \\
\text { birds }\end{array}$ & $\begin{array}{c}\text { All } \\
\text { birds }\end{array}$ & $\begin{array}{c}\text { Singing } \\
\text { birds }\end{array}$ & $\begin{array}{c}\text { All } \\
\text { birds }\end{array}$ \\
\hline & 3 & 4.33 & 8.00 & 1.33 & 2.22 \\
\hline & 3 & 6.00 & 10.33 & 0.91 & 1.81 \\
\hline & 3 & 10.67 & 16.33 & 1.16 & 2.20 \\
\hline & 3 & 13.67 & 19.67 & 0.81 & 1.96 \\
\hline
\end{tabular}

a Lines connect values that are not significantly different based on Duncan's test at $\mathrm{P}<0.05$. 
wetland obligates in marshes less than 1 ha in size.

Robbins et al. (1989) recently compiled habitat area requirements of breeding birds in 279 forest patches, ranging from 0.1 ha to over 3,000 ha, in the U.S. Middle Atlantic states. For each area-sensitive species (i.e., species having a significantly greater probability of occurrence with increasing forest patch size), they calculated the forest area at which the species' probability of occurrence was $50 \%$ of that species' maximum probability of occurrence. Two of the most common species in Rhode Island red maple swamps, the Canada Warbler and Northern Waterthrush, had $50 \%$ probabilities of occurrence in forests 400 ha and 200 ha in size, respectively. In Rhode Island, however, both of these species occurred in the smallest swamp studied $(0.5 \mathrm{ha})$. These results suggest that either (1) these species are responding to the larger forested landscape in which the swamps are located, or (2) they are not actually area-sensitive.

In this study, species richness increased at a relatively rapid rate until the wetlands exceeded about 6-8 ha in size. The same trend was apparent for singing birds and all birds observed (Figure 2). Richness continued to increase, but at a lower rate, in sites larger than 8 ha. Swift (1980, Swift et al. 1984) reported bird species richness for west-central Massachusetts red maple swamps 3045 ha in size. If species not considered as singing in the 
present study (such as the Brown-headed Cowbird, Blue Jay, and woodpeckers) are excluded from his results, there were 20-23 singing species recorded in each of Swift's (1980) four forested, very poorly drained study sites. As noted above, there were some methodological differences between the two studies, but the results are consistent (Figure 3), and suggest that species richness may continue to increase gradually as swamp size increases beyond the size range sampled in the present study.

A frequently discussed aspect of the species-area relationship is the slope or $z$ value of the regression equation (Connor and McCoy 1979). This parameter expresses the rate of increase in species richness, and may be influenced by many factors (e.g., the degree of isolation of the habitat patches; MacArthur and Wilson 1967). The $z$ values calculated for singing birds (0.38) and all birds $(0.28)$ in the present study are within the range of values reported in most other species-area research $(0.20$ to 0.40 ; MacArthur and Wilson 1967, Connor and McCoy 1979). Brown and Dinsmore (1986), in a study of species-area relationships in 30 marshes in Iowa ranging from 0.2 to 182 ha in size, calculated a $z$ value of 0.23 . Tyser (1983) studied 9 riverine marshes in Wisconsin ranging in size from 0.06 to 50 ha and found $z$ to equal 0.42 .

Connor and McCoy (1979) showed that the range of $\mathrm{z}$ values reported in species-area studies is more a function 


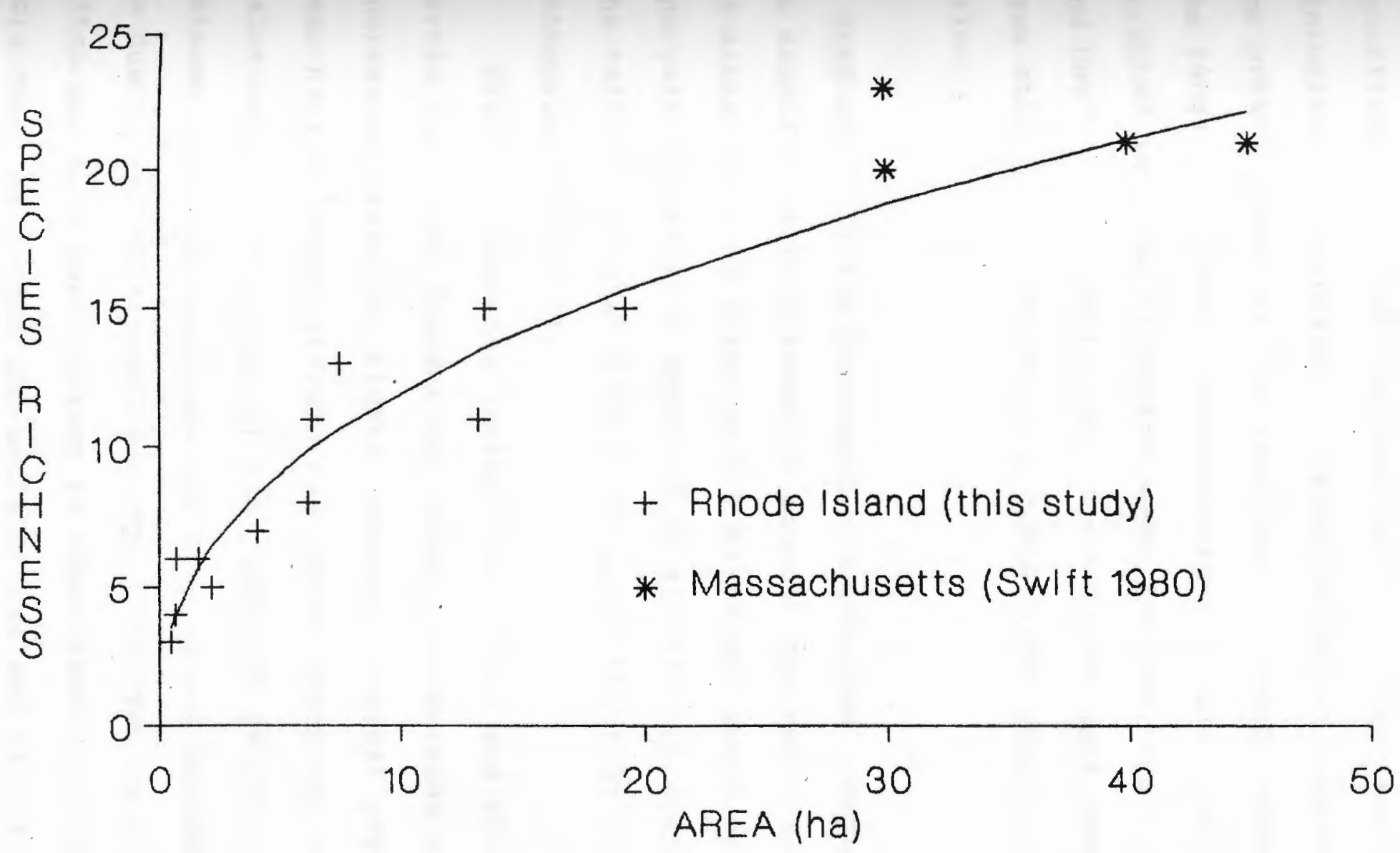

Figure 3. Species richness of singing birds in red maple swamps of southern New England as a function of swamp area. 
of the mathematics of the regression equation than the underlying data distribution, so the $z$ value may not be biologically meaningful. Further clouding interpretation in the present study is the size range of study sites. While the range is probably representative of the majority of forested wetlands in southern New England (e.g., see Golet and Davis 1982), it is more limited than most other speciesarea studies. A larger size range could yield a-different $z$ value.

Area and relative abundance.--Regression analysis showed no significant relationships between the relative abundance of either singing birds or all birds and swamp area, and analysis of variance revealed no significant differences in the relative abundance of birds among the four site size categories (Table 6 ).

Previous research (Oelke 1966, Lynch and Whigham 1984, Martin 1980) has found bird density to decrease with increasing area; the higher density of animal populations near habitat edges (Forman and Godron 1986) may explain this relationship. The lack of a significant relationship between relative abundance and area in the present study may be due to any of several factors. The results from all sites may have been subject to edge effect, as no plot was more than $105 \mathrm{~m}$ from the wetland edge and all sites had plots within $10 \mathrm{~m}$ of an edge. Further, the degree of "edge 
effect" in forested wetlands surrounded by predominately forested uplands is unknown. Changes in the composition of the avian community across the wetland/upland ecotone needs further research.

Implications for wetland protection and management. --The species-area relationship described above has important implications for wetland protection and management.

1. Red maple swamps as small as 0.5 ha supported several species of breeding birds, and the smallest site supported an obligate wetland species, the Northern Waterthrush. Thus, swamps which are much smaller than those currently protected by several states do appear to have significant habitat value. States with larger minimum sizes should consider reducing the minimum area required for protection.

2. Certain species were common and relatively abundant at most sites, suggesting that there is a characteristic association of avian species in red maple swamps. At least one of these species is a wetland obligate and several others (e.g., Canada Warbler, Veery) may prefer forested wetlands over other habitat types. If red maple swamp is the required or preferred habitat for these species, then protection of this habitat will be critical for the wellbeing of the species. 
3. Bird species richness increases rapidly with the size of swamps up to about 6-8 ha, after which it continues to increase, but at a lower rate. It may be tempting to equate species richness with habitat value and to conclude that sites below a certain size (e.g., 6 ha) are of lower value, or that above 6 ha habitat value does not change significantly. However, other considerations, along with richness, also may be important in determining habitat "value," for example, the preservation of rare species, forest-interior species, species restricted to certain habitats, or species of special interest. In this study, the important conclusion is that all sites, regardless of size, display breeding bird habitat value, and that "wetland species" breed in even very small sites.

\section{The Influence of Habitat}

Habitat and species richness.--Habitat variables used in analyses are listed by site in Appendix D. In stepwise multiple regression models, swamp area accounted for the majority of the variation in species richness for both singing birds $\left(R^{2}=0.81\right)$ and all birds $\left(R^{2}=0.84\right.$; Tables 7 and 8). All other significant $(P<0.05)$ independent variables were measures of shrub layer structure. For singing birds, significant variables included the combined foliage volume of medium and low (0-2 m) shrubs (+) and tall (2-4 m) shrub 
Table 7. Summary of stepwise regression analysis, including significant $(P<0.15)$ independent variables explaining variation in bird species richness and relative abundance.

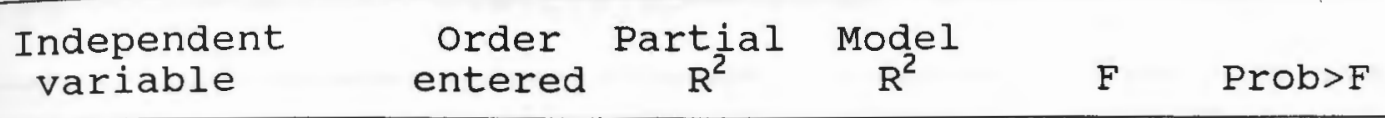

1. Species richness of singing birds (total per site)

$\begin{array}{lrrrrr}\text { Area (+) } & 1 & 0.811 & 0.811 & 42.996 & 0.0001 \\ \text { Medium+low shrub vol. }(+) & 2 & 0.083 & 0.894 & 7.080 & 0.0260 \\ \text { Tall shrub cover }(-) & 3 & 0.049 & 0.943 & 6.971 & 0.0297\end{array}$

2. Species richness of all birds (total per site)

$\begin{array}{llllrl}\text { Area ( }+ \text { ) } & 1 & 0.839 & 0.839 & 52.199 & 0.0001 \\ \text { Total shrub volume (+) } & 2 & 0.079 & 0.918 & 8.599 & 0.0167 \\ \text { Tall shrub cover (-) } & 3 & 0.020 & 0.938 & 2.621 & 0.1441 \\ \text { Low shrub cover (+) } & 4 & 0.022 & 0.960 & 3.913 & 0.0884\end{array}$

3. Relative abundance of singing birds (ave./plot/census)

$\begin{array}{llllll}\text { Depth of peat (+) } & 1 & 0.375 & 0.375 & 6.009 & 0.0342 \\ \text { Tree basal area (-) } & 2 & 0.187 & 0.562 & 3.831 & 0.0820 \\ \text { \% surface water (-) } & 3 & 0.110 & 0.672 & 2.684 & 0.1400 \\ \text { Surr. hab. divers. (+) } & 4 & 0.091 & 0.763 & 2.685 & 0.1453\end{array}$

4. Relative abundance of all birds (ave./plot/census)

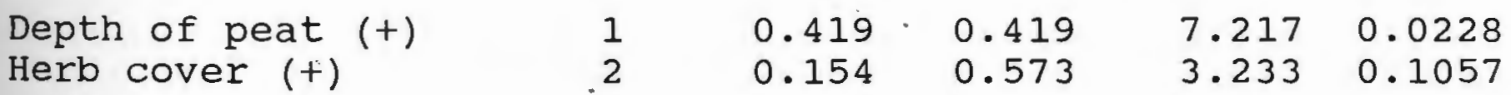


Table 8. Stepwise regression models, including significant $(P<0.05)$ independent variables explaining variation in bird species richness and relative abundance.

\section{Model}

Model $\mathrm{R}^{2}$

1. Species richness of singing birds $=$ $0.82+0.51$ (Area) - 0.08 (Tall shrub cover) + 0.28 (Medium and low shrub volume) 0.94

2. Species richness of all birds observed $=$ $1.72+0.79$ (Area) +0.28 (Total shrub volume) 0.92

3. Relative abundance of singing birds = $0.60+0.28$ (Depth of peat) 0.38

4. Relative abundance of all birds $=$ $1.64+0.26$ (Depth of peat) 
cover (-); for all birds, total shrub foliage volume (+) was significant. Simple correlations between species richness and individual habitat variables generally supported these results (Appendix E), as medium and low shrub variables were--besides area--the variables most strongly correlated with species richness.

The influence of shrub layer structure on avian species richness in red maple swamps has been documented-by swift et al. (1984). In a multiple regression analysis using 80 census plots (rather than study sites) as samples, they found significant relationships between avian richness and depth of peat $(+)$, density of shrubs $1-3 \mathrm{~m}$ high (+), density of shrubs 3-5 $\mathrm{m}$ high (-), and lowest overstory branch height (-). Both this study and that of swift et al. (1984) suggest that dense shrubs within 2-3 m of the ground, combined with a more open shrub layer above that level, support more avian species. Dense, low shrubs may provide escape cover and foraging and nesting substrates for a wide range of species. Other studies also have documented the importance of shrub layer structure, and foliage density in particular, to both bird species richness (Blake and Karr 1987, Martin 1988) and abundance (Best and stauffer 1986). However, none of these studies distinguished between shrub height categories. 
Habitat and relative abundance.--Peat depth was the only variable significantly related $(P<0.05)$ to avian relative abundance in stepwise multiple regression models. When peat depth was excluded from the analyses, no other variables were significant at $\mathrm{P}<0.05$, and only tree basal area was significant at the $\mathrm{P}<0.15$ level (and only for singing birds). Simple correlations (Appendix E) between relative abundance and most habitat variables also were very weak. Swift et al. (1984) found depth of peat to be highly significant $(\dot{P}<0.01)$ in explaining bird relative abundance. other significant variables in their model included surface water cover $(+)$ and density of shrubs 1-3 m tall (+).

Depth of peat may influence the vegetational community which, in turn, influences avian abundance. Herb cover and foliage height diversity (which is partly a function of herb cover) were the only habitat variables with significant simple correlations (-) with depth of peat (Appendix E). More research is needed on the possible relationships between the avian community, soil characteristics, vegetation, and perhaps also invertebrate prey abundance. Surface water cover, significantly related to bird abundance in the models of Swift et al. (1984), may also be a factor. While this was not a significant variable in Rhode Island, the census period in 1988 was relatively dry (precipitation in the area was $18 \%$ below normal during April-June; N.O.A.A. 1989), and many usually wet sites had 
little or no surface water.

It should be noted that there was limited variation in avian relative abundance among study sites in the present study. More research is needed to determine whether other mature, very poorly drained red maple swamps exhibit the same limited variation in relative abundance, and what factors influence or limit abundance. Future research should examine the relationships between avian abundance and habitat in more detail, for example by describing bird use of specific vegetation strata or the habitat requirements of individual species. 


\section{LITERATURE CITED}

A.O.U. 1983. Check-list of North American birds, 6th edition. American ornithologist's Union, Allen Press, Lawrence, Kansas. $877 \mathrm{pp}$.

Anderson, K.S., and H.K. Maxfield. 1962. Sampling passerine birds in a wooded swamp in southeastern Massachusetts. wilson Bull. 74:381-385.

August, P.V. 1983. The role of habitat complexity and heterogeneity in structuring tropical mammal communities. Ecology 64:1495-1507.

Beecher, W.J. 1942. Nesting birds and the vegetation substrate. Chicago ornith. Soc., Chicago, Illinois. $69 \mathrm{pp}$.

Best, L.B., and D.F. Stauffer. 1986. Factors confounding evaluation of bird-habitat relationships. Pages 209216 in J. Verner, M.L. Morrison, and C.J. Ralph, eds. Wildlife 2000 , modeling habitat relationships of terrestrial vertebrates. Univ. Wisconsin Press, Madison.

Black, I.H., and G.M. Seeley. 1953. Breeding bird census no. 12: wet deciduous forest. Audubon Field Notes 7:340341 .

Blake, J.G., and J.R. Karr. 1987. Breeding birds of isolated woodlots: area and habitat relationships. Ecology $68: 1724-1734$.

Blondel, J., C. Ferry, and B. Frochot. 1981. Point counts with unlimited distance. Pages 414-420 in C.J. Ralph and J.M. Scott, eds. Estimating the numbers of terrestrial birds. Stud. Avian Biol. 6.

Brown, M., and J.J. Dinsmore. 1986. Implications of marsh size and isolation for marsh bird management. $J$. Wildl. Manage. 50:392-397.

Canfield, R. 1941. Application of the line-interception method in sampling range vegetation. J. Forestry 39 : 388-394.

Clark, K.L., D.L. Euler, and E. Armstrong. 1983. Habitat associations of breeding birds in cottage and natural areas of central Ontario. Wilson Bull. 95:77-96. 
Connor, E.F., and E.D. McCoy. 1979. The statistics and biology of the species-area relationship. Am. Nat. $113: 791-833$.

Daubenmire, R.F. 1959. Canopy coverage method of vegetation analysis. Northwest Sci. 33:43-64.

DeGraaf, R.M. 1987. Breeding birds and gypsy moth defoliation: short-term responses of species and guilds. Wildl. Soc. Bull. 15:217-221.

Dowdy, S., and S. Wearden. 1983. Statistics for research. John Wiley \& Sons, New York. $537 \mathrm{pp}$.

Edwards, D.K., G.L. Dorsey, and J.A. Crawford. 1981. A comparison of three avian census methods. Pages 170176 in C.J. Ralph and J.M. Scott, eds. Estimating the numbers of terrestrial birds. Stud. Avian Biol. 6 .

Emlen, J.T. 1971. Population densities of birds derived from transect counts. Auk 88:323-342.

Emlen, J.T. 1977. Estimating breeding season bird densities from transect counts. Auk 94:455-468.

Forman, R.T.T., and M. Godron. 1986. Landscape ecology. John Wiley \& Sons, New York. 619pp.

Goldsmith, F.B., C.M. Harrison, and A.J. Morton. 1986. Description and analysis of vegetation. Pages 437-524 in P.D. Moore and S.B. Chapman, eds. Methods in plant ecology, second edition. Blackwell scientific Publications, oxford.

Golet, F.C., A.J.K. Calhoun, D.J. Lowry, W.R. DeRagon, and A.J. Gold, in prep. The ecology of red maple swamps in the glaciated Northeastern United States: a community profile. U.S. Fish Wildl. Serv. Biol. Rep. 90 (_).

Golet, F.C., and A.F. Davis. 1982. Inventory and habitat evaluation of the wetlands of Richmond, Rhode Island. Occas. Pap. Environ. Sci: No. 1. Univ. Rhode Island, Kingston. $48 \mathrm{pp}$.

Gotfryd, A., and R.I.C. Hansell. 1986. Prediction of bird community metrics in urban woodlots. Pages 321-326 in J. Verner, M.L. Morrison, and C.J. Ralph, eds. Wildlife 2000: modeling habitat relationships of terrestrial vertebrates. Univ. Wisconsin Press, Madison.

Gottfried, B.M. 1979. Small mammal populations in woodlot islands. Am. Midl. Nat. 102:105-112. 
James, F.C., and N.O. Wamer. 1982. Relationships between temperate forest bird communities and vegetation structure. Ecology 63:159-171.

Karr, J.R. 1981. Surveying birds with mist nets. Pages 62-67 in C.J. Ralph and J.M. Scott, eds. Estimating the numbers of terrestrial birds. Stud. Avian Biol. 6 .

Kroodsma, R.L. 1984. Effect of edge on breeding forest bird species. Wilson Bull. 96:426-436.

Lack, D. 1942. Ecological features of bird faunas of small British islands. J. Anim. Ecol. 11:9-36.

Linehan, J.T., R.E. Jones, and J.R. Longcore. 1967. Breeding bird populations in Delaware's urban woodlots. Audubon Field Notes 21:641-646.

Lynch, J.F., and D.F. Whigham. 1984. Effects of forest fragmentation on breeding bird communities in Maryland, USA. Biol. Conserv. 28:287-324.

MacArthur, R.H. 1964. Environmental factors affecting bird species diversity. Am. Nat. 98:387-397.

MacArthur, R.H., and J.W. MacArthur. 1961. On bird species diversity. Ecology 42:594-598.

MacArthur, R.H., and E.O. Wilson. 1967. The theory of island biogeography. Princeton Univ. Press, Princeton, New Jersey. $203 \mathrm{pp}$.

Martin, T.E. 1980. Diversity and abundance of spring migratory birds using habitat islands on the Great Plains. Condor 82:430-439.

Martin, T.E. 1988. Habitat and area effects on forest bird assemblages: is nest predation an influence? Ecology $69: 74-84$.

Meyers, P.N., T.W. Gutzke, and H.P. Laskowski. 1981. Breeding bird census no. 6: red maple-pin oak-mixed hardwoods. Am. Birds 35:51.

Morrison, M.L., I.C. Timossi, and K.A. With. 1987. Development and testing of linear regression models predicting bird-habitat relationships. J. Wildl. Manage. 51:247-253.

N.O.A.A. 1989. New England climatic data annual summary. Nat. Climatic Data Center, Asheville, North Carolina. 
oelke, H. 1966. 35 years of breeding-bird census work in Europe. Audubon Field Notes 20:635-642.

opdam, P. , G. Rijsdijk, and F. Hustings. 1985. Bird communities in small woods in an agricultural

landscape: effects of area and isolation. Biol. conserv. $34: 333-352$.

Peitzmeier, J. 1950. Untersuchengen uber die siedlungsdichte der Vogelwelt in kleinen Geholzen in Westfalen. Nat. Heimat 10:30-37.

preston, F.W. 1960. Time and space and the variation of species. Ecology 41:611-627.

preston, F.W. 1962. The ecological distribution of commonness and rarity. Ecology 43:185-215, 410-432.

Rector, D. 1981. Soil Survey of Rhode Island. U.S. Dept. Agric., Soil Conserv. Serv., West Warwick, Rhode Island.

Robbins, C.S., D.K. Dawson, and B.A. Dowell. 1989. Habitat area requirements of breeding forest birds of the Middle Atlantic States. Wildl. Monogr. 103:1-34.

Seeley, G.M. 1954. Breeding bird census no. 6: wet deciduous forest. Audubon Field Notes 8:366.

Seeley, G.M. 1955. Breeding bird census no. 3: wet deciduous forest. Audubon Field Notes 9:412-413.

Seeley, G.M. 1956. Breeding bird census no. 3: wet deciduous forest. Audubon Field Notes 10:420.

Seeley, G.M. 1957. Breeding bird census no. 1: wet deciduous forest. Audubon Field Notes 11:436.

Seeley, G.M. 1966. Breeding bird census no. 2: wet deciduous forest. Audubon Field Notes 20:608.

Shannon, C.E. 1948. The mathematical theory of communication. Pages 3-91 in C.E. Shannon and Weaver, eds. The mathematical theory of communication. Univ. Illinois Press, Urbana.

Simberloff, D. 1972. Models in biogeography. Pages 160-191 in T.J.M. Schopf, ed. Models in paleobiology. Freeman, San Francisco, California.

Simberloff, D. 1976. Experimental zoogeography of islands: effects of island size. Ecology 57:629-648. 
Simberloff, D., and L.G. Abele. 1982. Refuge design and island biogeographic theory: effects of fragmentation. Am. Nat. 120:41-50.

Slack, R.S., P.G. Valka, V.J. Lucid, and J. McMullen. 1975. Breeding bird census no. 3: red maple forest. Am.

Birds 29:1082-1083.

Swift, B.L. 1980. Breeding bird habitats in forested wetlands of west-central Massachusetts. M.S. Thesis, Univ. Massachusetts, Amherst. 90pp.

Swift, B.L., J.S. Larson, and R.M. DeGraaf. 1984 . Relationship of breeding bird density and diversity to habitat variables in forested wetlands. Wilson Bull. $96: 48-59$.

Taylor, G.W. 1984. Breeding bird census no. 3: red maple swamp. Am. Birds $38: 69$.

Tiner, R.W. 1989. Wetlands of Rhode Island. U.S. Fish Wildl. Serv., Nat. Wetlands Inventory, Newton Corner, Massachusetts. $71 \mathrm{pp}$.

Tyser, R.W. 1983. Species-area relations of cattail marsh avifauna. Passenger Pigeon 45:125-128.

Weller, M.W. 1979. Wetland habitats. Pages 210-234 in P.E. Greeson, J.R. Clark, and J.E. Clark, eds. Wetland functions and values: the state of our understanding. Am. Water Resour. Assoc., Minneapolis, Minnesota.

Whitcomb, R.F., C.S. Robbins, J.F. Lynch, B.L. Whitcomb, M.K. Klimkiewicz, and D. Bystrak. 1981. Effects of forest fragmentation on avifauna of the eastern deciduous forest. Pages 125-206 in R.L. Burgess and B.M. Sharpe, eds. Forest island dynamics in man-dominated landscapes. Springer-Verlag, New York.

Widoff, L. 1988. Maine wetlands conservation priority plan. Maine Bur. Parks Recreation, state Planning Office, Augusta. $91 \mathrm{pp}$.

Wright, W.R., and Sautter, E.H. 1988. Soils of Rhode Island landscapes. Univ. Rhode Island Agric. Exp. Sta. Bull. 429 , Kingston. 42 pp. 
Appendix A. Location of study sites.

Site

Kenyon

Muddy Brook

Tuckertown

Tootell

carolina

Turnpike

Fairgrounds

Decoppet

Trustom

Narragansett

Townsend

Dead Swamp
Hope Valley

Carolina

Kingston

Hope Valley

Carolina

Hope Valley

Kingston

Hope Valley

Kingston

Narragansett Pier

Kingston

slocum
Latitude Long itude

$41^{\circ} 30^{\prime} 35^{\prime \prime} \quad 71^{\circ} 39^{\prime} 20^{\prime \prime}$ $41^{\circ} 28^{\prime} 30^{\prime \prime} \quad 71^{\circ} 38^{\prime} 20^{\prime \prime}$ $41^{\circ} 25^{\prime} 48^{\prime \prime} \quad 71^{\circ} 32^{\prime} 45^{\prime \prime}$ $41^{\circ} 30^{\prime} 15^{\prime \prime} \quad 71^{\circ} 40^{\prime} 00^{\prime \prime}$ $41^{\circ} 29^{\prime} 10^{\prime \prime} \quad 71^{\circ} 42^{\prime} 25 "$ $41^{\circ} 32^{\prime} 15^{\prime \prime} \quad 71^{\circ} 40^{\prime} 15^{\prime \prime}$ $41^{\circ} 29^{\prime} 45^{\prime \prime} \quad 71^{\circ} 33^{\prime} 05^{\prime \prime}$ $41^{\circ} 31^{\prime} 08^{\prime \prime} \quad 71^{\circ} 38^{\prime} 55^{\prime \prime}$ $41^{\circ} 22^{\prime} 35^{\prime \prime} \quad 71^{\circ} 33 \cdot 35^{\prime \prime}$ $41^{\circ} 25^{\prime} 00^{\prime \prime} \quad 71^{\circ} 28^{\prime} 15^{\prime \prime}$ $41^{\circ} 25^{\prime} 30^{\prime \prime} \quad 71^{\circ} 32^{\prime} 00^{\prime \prime}$ $41^{\circ} 36^{\prime} 50^{\prime \prime} \quad 71^{\circ} 33^{\prime} 08^{\prime \prime}$ 
Appendix B-1. Relative abundance of singing birds in 12 Rhode Island red maple swamps, based on 6 censuses during the 1988 breeding season. Relative abundance is expressed as birds per $0.28^{-h a}$ plot per census.

\begin{tabular}{|c|c|c|c|c|c|c|c|c|c|c|c|c|c|c|}
\hline \multirow[b]{2}{*}{ Species } & \multicolumn{12}{|c|}{ Study site ${ }^{a}$} & \multirow{2}{*}{\multicolumn{2}{|c|}{$\begin{array}{c}\text { No. } \\
n \text { sites }\end{array}$}} \\
\hline & KE & MB & TU & TO & $\mathrm{CA}$ & TP & FA & $D E$ & TR & NA & TN & DS & & \\
\hline Canada Warbler & 0.50 & 0.50 & & & 0.33 & 0.17 & 0.37 & 0.20 & 0.25 & 0.07 & 0.05 & 0.33 & 75 & 10 \\
\hline Gray Catbird & 0.17 & 0.17 & 0.67 & 0.17 & 0.17 & 0.06 & 0.20 & 0.17 & 0.08 & 0.19 & 0.07 & 0.04 & 46 & 12 \\
\hline Black-and-white Warb & & & & 0.17 & & 0.17 & 0.07 & 0.27 & 0.14 & 0.03 & 0.12 & 0.19 & 45 & 8 \\
\hline Veery & & & 0.33 & 0.42 & & 0.06 & 0.03 & 0.17 & 0.08 & 0.06 & 0.10 & 0.07 & 33 & 9 \\
\hline No. Waterthrush & 0.33 & & & 0.08 & 0.17 & 0.28 & & 0.27 & & & 0.03 & 0.14 & 32 & 7 \\
\hline Common Yellowthroat & & 0.17 & & 0.17 & & & 0.03 & & 0.06 & 0.03 & 0.08 & 0.06 & 18 & 7 \\
\hline Great $\mathrm{Cr}$. $\mathrm{Flycatcher}$ & & & & & 0.08 & 0.06 & 0.03 & 0.17 & & 0.07 & 0.02 & 0.02 & 16 & 7 \\
\hline Rufous-sided Towhee & & & & & & & & & 0.03 & & 0.13 & 0.05 & 13 & 3 \\
\hline Tufted Titmouse & & $\cdot$ & & 0.08 & & & & 0.03 & 0.03 & 0.01 & 0.05 & 0.05 & 11 & 6 \\
\hline Red-eyed Vireo & & & 0.33 & & 0.08 & 0.06 & 0.10 & 0.07 & & 0.01 & & 0.01 & 11 & 7 \\
\hline American Redstart & & & & & & & & 0.23 & 0.08 & & & & 10 & 2 \\
\hline Wood Thrush & & & 0.17 & & & & & & 0.03 & & & 0.02 & 4 & 3 \\
\hline American Robin & & & & & & & & & 0.03 & 0.04 & & & 4 & 2 \\
\hline Blue-winged Warbler & & & & & & & 0.03 & & & & 0.03 & 0.01 & 4 & 3 \\
\hline Northern Oriole & & & & & & & & & & 0.04 & & 0.01 & 4 & 2 \\
\hline Carolina Wren & & & & & & & & & 0.03 & & 0.03 & & 3 & 2 \\
\hline House Wren & & & 0.33 & & & & & 0.03 & & & & & 3 & 2 \\
\hline White-eyed Vireo & & & & & & & & & 0.06 & & 0.02 & & 3 & 2 \\
\hline Chestnut-sided Warbl & ler & & & & & & & 0.07 & 0.03 & & & & 3 & 2 \\
\hline Scarlet Tanager & & & & & & & & & & & 0.02 & 0.02 & 3 & 2 \\
\hline Rose-breasted Grosbe & eak & 0.17 & & & & & & & & 0.03 & & & 3 & 2 \\
\hline Black-thr. Green War & & & & & & & & & & & 0.03 & & 2 & 1 \\
\hline Black-capped Chickad & dee & & & & & & & & & & 0.02 & & 1 & 1 \\
\hline Yellow-throated Vire & & & & & & & & & & & & 0.01 & 1 & 1 \\
\hline Northern Cardinal & & & 0.17 & & & & & & & & & & 1 & 1 \\
\hline Unidentified species & & & & & & & & & 0.03 & & & & 1 & 1 \\
\hline Total & $\overline{1.00}$ & $\overline{1.00}$ & $\overline{2.00}$ & $\overline{1.08}$ & $\overline{0.83}$ & $\overline{0.83}$ & $\overline{0.87}$ & $\overline{1.67}$ & $\overline{0.94}$ & $\overline{0.58}$ & 0.80 & 1.05 & 350 & \\
\hline Species $r$ ichness ${ }^{b}$ & 3 & 4 & 6 & 6 & 5 & 7 & 8 & 11 & 13 & 11 & 15 & 15 & & \\
\hline
\end{tabular}

a study sites: KE, Kenyon; MB, Muddy Brook; TU, Tuckertown; TO, Tootell; FA, Fairgrounds; DE, DeCoppet; TR, Trustom; NA, Narragansett; TN, Townsend; DS, Dead Swamp.

b Unidentified species are not included in species richness totals. 
Appendix B-2. Relative abundance of all birds observed in 12 Rhode Island red maple swamps, based on 6 censuses during the 1988 breeding season. Relative abundance is expressed as birds per 0.28 -ha plot per census.

\begin{tabular}{|c|c|c|c|c|c|c|c|c|c|c|c|c|c|c|}
\hline \multirow[b]{2}{*}{ Species } & \multicolumn{12}{|c|}{ Study site } & \multirow{2}{*}{$n$} & \multirow{2}{*}{$\begin{array}{l}\text { No. } \\
\text { sites }\end{array}$} \\
\hline & $\mathrm{KE}$ & MB & TU & TO & CA & TP & FA & DE & TR & NA & TN & DS & & \\
\hline Black-cap. Chickadee & 0.33 & 0.50 & & 0.25 & 0.42 & 0.28 & 0.23 & 0.17 & 0.17 & 0.43 & 0.40 & 0.37 & 122 & 11 \\
\hline Canada Warbler & 0.50 & 0.50 & & & 0.33 & 0.17 & 0.40 & 0.30 & & 0.07 & 0.08 & 0.43 & 89 & 10 \\
\hline veery & & 0.17 & 0.33 & 0.42 & 0.08 & 0.33 & 0.13 & 0.40 & 0.14 & 0.10 & 0.27 & 0.19 & 75 & 11 \\
\hline Gray Catbird & 0.17 & 0.17 & 0.83 & 0.17 & 0.17 & 0.22 & 0.27 & 0.37 & 0.14 & 0.21 & 0.13 & 0.05 & 66 & 12 \\
\hline Black-and-wh. Warbler & & 0.17 & & 0.17 & & 0.17 & 0.07 & 0.27 & 0.14 & 0.06 & 0.12 & 0.20 & 49 & 9 \\
\hline Tufted Titmouse & & & & 0.08 & & 0.22 & 0.03 & 0.20 & 0.33 & 0.04 & 0.07 & 0.17 & 45 & 8 \\
\hline Common Yellowthroat & & 0.17 & & 0.17 & & & 0.10 & 0.03 & 0.14 & 0.06 & 0.13 & 0.17 & 38 & 8 \\
\hline No. Waterthrush & 0.33 & & & 0.08 & 0.17 & 0.33 & & 0.30 & & & -0.03 & 0.14 & 34 & 7 \\
\hline Blue Jay & & & & 0.08 & 0.08 & & & & 0.03 & 0.17 & 0.12 & 0.12 & 32 & 6 \\
\hline American Robin & & & 0.17 & & & & & & 0.17 & 0.18 & & 0.07 & 26 & 4 \\
\hline Rufous-sided Towhee & 0.17 & & & 0.08 & & & & 0.03 & 0.03 & 0.04 & 0.13 & 0.10 & 23 & 7 \\
\hline Great $\mathrm{Cr}$. Flycatcher & & & & & 0.08 & 0.06 & 0.03 & 0.17 & & 0.10 & 0.02 & 0.02 & 18 & 7 \\
\hline Red-eyed Vireo & & & 0.33 & & 0.08 & 0.06 & 0.10 & 0.07 & & 0.01 & & 0.01 & 11 & 7 \\
\hline American Redstart & & & & & & & & 0.23 & 0.08 & & & & 10 & 2 \\
\hline Northern Oriole & & 0.17 & & & & & & & & 0.11 & & 0.01 & 10 & 3 \\
\hline White-br. Nuthatch & & & & & & & & & 0.06 & & 0.07 & 0.02 & 8 & 3 \\
\hline Brown Creeper & 0.17 & 0.17 & 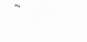 & 0.17 & & 0.06 & & & & & 0.03 & & 7 & 5 \\
\hline Hairy Woodpecker & & & & & & & & & & 0.03 & & 0.05 & 6 & 2 \\
\hline Northern Flicker & 0.33 & & & & & & 0.10 & & & & & 0.01 & 6 & 3 \\
\hline Song Sparrow & & & & & & & 0.20 & & & & & & 6 & 1 \\
\hline Blue-gray Gnatcatcher & & & & & & & & 0.03 & 0.11 & & & & 5 & 2 \\
\hline Wood Thrush & & & 0.17 & & & & & & 0.03 & & & 0.04 & 5 & 3 \\
\hline Rose-breasted Grosbea & & 0.17 & & & & & & & & 0.06 & & & 5 & 2 \\
\hline Brown-headed Cowbird & & & & & & 0.06 & & & & & 0.05 & 0.01 & 5 & 3 \\
\hline Downy Woodpecker & & & & & & & & 0.03 & 0.08 & & & & 4 & 2 \\
\hline Blue-winged Warbler & & & & & & & 0.03 & & & & 0.03 & 0.01 & 4 & 3 \\
\hline Carolina Wren & & & & & & & & & 0.03 & & 0.03 & & 3 & 2 \\
\hline House Wren & & & 0.33 & & & & & 0.03 & & & & & 3 & 2 \\
\hline White-eyed Vireo & & & & & & & & & 0.06 & & 0.02 & & 3 & 2 \\
\hline Chestnut-sided Warble & & & & & & & & 0.07 & 0.03 & & & & 3 & 2 \\
\hline Scarlet Tanager & & & & & & & & & & & 0.02 & 0.02 & 3 & 2 \\
\hline Common Grackle & & & & & 0.08 & & & & & & & 0.02 & 3 & 2 \\
\hline Black-thr. Green Warb & bler & & & & & & - & & & & 0.03 & & 2 & 1 \\
\hline Ruffed Grouse & & & & & & & 0.03 & & & & & & 1 & 1 \\
\hline Eastern Phoebe & & & & $\cdot$ & & & 0.03 & & & & & & 1 & 1 \\
\hline Yellow-throated Vireo & & & & & & & & & & & & 0.01 & 1 & 1 \\
\hline Prairie Warbler & & & & & & & & 0.03 & & & & & 1 & 1 \\
\hline Ovenbird & & & & & & & & & & & & 0.01 & 1 & 1 \\
\hline Northern Cardinal & & & 0.17 & & & & - & & & & & & 1 & 1 \\
\hline Unident. woodpeckers & 0.17 & & & 0.08 & & & & & & & 0.02 & & 3 & 3 \\
\hline Unident. species & & & & & 0.08 & 0.17 & 0.03 & 0.03 & 0.03 & 0.03 & 0.05 & 0.10 & 20 & 8 \\
\hline Total & $\overline{2.17}$ & $\overline{2.17}$ & $\overline{2.33}$ & $\overline{1.75}$ & $\overline{1.58}$ & $\overline{2.11}$ & $\overline{1.80}$ & $\overline{2.77}$ & $\overline{2.03}$ & $\overline{1.68}$ & $\overline{1.85}$ & $\overline{2.36}$ & $\overline{758}$ & \\
\hline Species richness ${ }^{b}$ & 8 & 9 & 7 & 11 & 9 & 11 & 14 & 17 & 18 & 15 & 20 & 24 & 39 & \\
\hline
\end{tabular}

See Appendix B-1 for full names of study sites.

b Unidentified species are not included in species richness totals, except for unidentified woodpeckers (all picoides species) in sites where these species did not otherwise occur. 
Appendix $C$. Common and scientific names of bird species observed at 12 Rhode Island red maple swamps during the 1988 breeding season ${ }^{\mathrm{a}}$.

Common name

American Robin

American Redstart

Black-capped Chickadee

Black-and-white warbler

Black-throated Green Warbler

Blue-gray Gnatcatcher

Blue-winged Warbler

Blue Jay

Brown-headed Cowbird

Brown Creeper

Canada Warbler

Carolina Wren

Chestnut-sided Warbler

common Grackle

Common Yellowthroat

Downy Woodpecker

Eastern Phoebe

Gray Catbird

Great Crested Flycatcher

Hairy Woodpecker

House Wren

Northern Waterthrush

Northern Cardinal

Northern oriole

Northern Flicker (yellow-shafted)

Ovenbird

Prairie Warbler

Red-eyed Vireo

Rose-breasted Grosbeak

Ruffed Grouse

Rufous-sided Towhee

Scarlet Tanager

Song Sparrow

Tufted Titmouse

Veery

White-eyed Vireo

White-breasted Nuthatch

Wood Thrush

Yellow-throated vireo
Scientific name

Turdus migratorius

Setophaga ruticilla

Parus atricapillus

Mniotilta varia

Dendroica virens

Polioptila caerulea

Vermivora pinus

Cyanocitta cristata

Molothrus ater

Certhia americana

Wilsonia canadensis

Thryothorus ludovicianus

Dendroica pensylvanica

Quiscalus quiscula

Geothlypis trichas

Picoides pubescens

Sayornis phoebe

Dumetella carolinensis

Myiarchus crinitus

Picoides villosus

Troglodytes aedon

Seiurus noveboracensis

Cardinalis cardinalis

Icterus galbula

Colaptes auratus

Seiurus aurocapillus

Dendroica discolor

Vireo olivaceus

Pheucticus ludovicianus

Bonasa umbellus

Pipilo erythrophthalmus

Piranga olivacea

Melospiza melodia

parus bicolor

Catharus fuscescens

vireo griseus

Sitta carolinensis

Hylocichla mustelina

vireo flavifrons

Taxonomic source: A.O.U. 1983. 
Appendix D. Mean values for independent variables used in analyses, by site. Refer to Appendix E for variable names.

\begin{tabular}{|c|c|c|c|c|c|c|c|c|c|c|c|}
\hline site & $\begin{array}{l}\text { No. } \\
\text { plots }\end{array}$ & $\begin{array}{l}\text { AREA } \\
\text { (ha) }\end{array}$ & $\begin{array}{l}\text { SHDV } \\
\left({ }^{*}\right)\end{array}$ & $\begin{array}{c}\text { TDEN } \\
\text { (stems } / \text { ha) }\end{array}$ & $\begin{array}{c}\text { DDEN } \\
\text { (stems/ha) }\end{array}$ & $\begin{array}{l}\text { IBAS } \\
\left(\mathrm{m}^{2} / \mathrm{ha}\right)\end{array}$ & $\begin{array}{l}\text { DBAS } \\
\left(\mathrm{m}^{2} / \mathrm{ha}\right)\end{array}$ & $\begin{array}{r}\text { TDIV } \\
\left({ }^{*}\right)\end{array}$ & $\begin{array}{r}\text { THGT } \\
(\mathrm{m})\end{array}$ & $\begin{array}{r}\text { Ccov } \\
(\%)\end{array}$ & $\begin{array}{r}\text { TSCV } \\
(\%)\end{array}$ \\
\hline Kenyon & 1 & 0.49 & 0.00 & 476.19 & 29.76 & 19.65 & 2.94 & 0.28 & 15.91 & 89.68 & 59.38 \\
\hline Muddy Brook & 1 & 0.64 & 0.67 & 416.67 & 14.88 & 22.23 & 0.39 & 0.71 & 15.91 & 85.84 & 81.70 \\
\hline Tuckertown & 1 & 0.67 & 0.62 & 491.07 & 89.29 & 17.06 & 1.19 & 0.00 & 14.57 & 96.16 & 29.91 \\
\hline Tootell & 2 & 1.6 & 0.69 & 513.39 & 119.05 & 17.19 & 1.88 & 0.28 & 13.50 & 82.96 & 42.41 \\
\hline Carol ina & 2 & 2.19 & 0.57 & 342.26 & 29.76 & 27.25 & 0.34 & 0.62 & 17.71 & 91.48 & 40.40 \\
\hline Turnpike & 3 & 4.02 & 0.45 & 471.23 & 29.76 & 30.33 & 2.39 & 0.68 & 15.16 & 84.40 & 60.27 \\
\hline Fairgrounds & 5 & 6.17 & 1.57 & 514.88 & 71.43 & 26.72 & 1.87 & 0.00 & 16.03 & 82.34 & 60.98 \\
\hline DeCoppet & 5 & 6.33 & 0.64 & 592.26 & 47.62 & 23.83 & 1.25 & 0.49 & 13.90 & 91.31 & 51.16 \\
\hline Trustom & 6 & 7.43 & 0.55 & 379.46 & 64.48 & 23.61 & 2.40 & 0.07 & 13.89 & 86.48 & 56.62 \\
\hline Narragansett & 12 & 13.21 & 0.10 & 1001.98 & 100.45 & 23.22 & 1.10 & 0.49 & 13.61 & 98.92 & 37.05 \\
\hline Townsend & 10 & 13.49 & 0.48 & 441.96 & 47.62 & 25.02 & 0.96 & 0.38 & 14.45 & 93.78 & 47.72 \\
\hline Dead Swamp & 14 & 19.24 & 0.23 & 493.20 & 89.29 & 25.26 & 3.05 & 0.05 & 16.36 & 84.09 & 44.45 \\
\hline Mean & & 6.29 & 0.54 & 511.21 & 61.12 & 23.45 & 1.65 & 0.34 & 15.08 & 88.95 & 51.00 \\
\hline stan. error & & 1.76 & 0.12 & 48.49 & 9.55 & 1.15 & 0.27 & 0.08 & 0.38 & 1.57 & 3.99 \\
\hline Minimum & & 0.49 & 0.00 & 342.26 & 14.88 & 17.06 & 0.34 & 0.00 & 13.50 & 82.34 & 29.91 \\
\hline Maximum & & 19.24 & 1.57 & 1001.98 & 119.05 & 30.33 & 3.05 & 0.71 & 17.71 & 98.92 & 81.70 \\
\hline
\end{tabular}

\begin{tabular}{|c|c|c|c|c|c|c|c|c|c|c|c|}
\hline Site & $\begin{array}{r}\text { MSCV } \\
(\%)\end{array}$ & $\begin{array}{l}\text { LSCV } \\
(\%)\end{array}$ & $\begin{array}{r}\text { MLCV } \\
(\%)\end{array}$ & $\begin{array}{r}\text { TOCV } \\
(\%)\end{array}$ & $\begin{array}{l}\text { HECV } \\
(\%)\end{array}$ & $\begin{array}{c}\text { WATR } \\
(\%)\end{array}$ & $\begin{array}{l}\text { PEAT } \\
(\mathrm{m})\end{array}$ & $\begin{array}{r}\text { TSVL } \\
(\%)\end{array}$ & $\begin{array}{r}\text { MLVL } \\
(\%)\end{array}$ & $\begin{array}{r}\text { TOVL } \\
(\%)\end{array}$ & $\begin{array}{l}\text { FHD } \\
\left({ }^{*}\right)\end{array}$ \\
\hline Kenyon & 17.86 & 2.68 & 20.54 & 79.91 & 0.00 & 33.33 & 2.5 & 22.72 & 26.72 & 24.72 & 0.69 \\
\hline Muddy Brook & 10.27 & 3.13 & 13.39 & 95.09 & 51.34 & 17.78 & 0.8 & 28.30 & 33.04 & 30.67 & 1.07 \\
\hline Tuckertown & 42.41 & 4.91 & 47.32 & 77.23 & 0.00 & 11.67 & 2.7 & 8.97 & 26.50 & 17.73 & 0.69 \\
\hline Tootell & 30.13 & 7.37 & 37.50 & 79.91 & 0.45 & 67.50 & 1.4 & 14.58 & 28.06 & 21.32 & 0.71 \\
\hline Carol ina & 31.47 & 9.38 & 40.85 & 81.25 & 24.78 & 10.56 & 0.7 & 10.47 & 23.56 & 17.01 & 0.98 \\
\hline Turnpike & 14.88 & 2.68 & 17.56 & 77.83 & 49.85 & 8.52 & 2.2 & 13.18 & 35.94 & 24.56 & 1.07 \\
\hline Fairgrounds & 24.64 & 5.54 & 30.18 & 91.16 & 16.52 & 13.67 & 1.6 & 20.93 & 40.40 & 30.66 & 0.93 \\
\hline DeCoppet & 28.66 & 6.70 & 35.36 & 86.52 & 12.23 & 4.56 & 2.5 & 21.21 & 37.27 & 29.24 & 0.89 \\
\hline Trustom & 28.79 & 4.61 & 33.41 & 90.03 & 56.99 & 0.00 & 0.3 & 19.11 & 39.77 & 29.44 & 1.08 \\
\hline Narragansett & 27.08 & 9.97 & 37.05 & 74.11 & 36.53 & 6.62 & 0.5 & 11.08 & 24.12 & 17.60 & 1.03 \\
\hline Townsend & 45.22 & 4.91 & 50.13 & .97 .86 & 4.73 & 3.11 & 1.8 & 16.63 & 42.70 & 29.67 & 0.79 \\
\hline Dead Swamp & 30.58 & 15.34 & 45.92 & 90.37 & 16.23 & 2.30 & 2.2 & 15.72 & 29.05 & 22.39 & 0.92 \\
\hline Mean & 27.67 & 6.43 & 34.10 & 85.11 & 22.47 & 14.97 & 1.60 & 16.91 & 32.26 & 24.58 & 0.90 \\
\hline Stan. error & 2.92 & 1.06 & 3.42 & 2.23 & 6.13 & 5.42 & 0.24 & 1.66 & 1.95 & 1.54 & 0.04 \\
\hline Minimum & 10.27 & 2.68 & 13.39 & 74.11 & 0.00 & 0.00 & 0.31 & 8.97 & 23.56 & 17.01 & 0.69 \\
\hline Maximum & 45.22 & 15.34 & 50.13 & 97.86 & 56.99 & 67.50 & 2.66 & 28.30 & 42.70 & 30.67 & 1.08 \\
\hline
\end{tabular}

* Shannon diversity index (Shannon 1948) 
Appendix E. Pearson correlation coefficients and

significance of correlations for all pairs of variables used in analyses. ${ }^{\text {a }}$ Refer to Appendix E for variable names.

\begin{tabular}{|c|c|c|c|c|c|c|c|c|c|c|c|c|}
\hline & BRCHS & BRCHA & BDENS & BDENA & AREA & SHDV & TDEN & DDEN & TBAS & DBAS & TDIV & THGT \\
\hline BRCHS & & $\begin{array}{l}0.95 \\
0.0001\end{array}$ & $\begin{array}{r}-0.14 \\
0.67\end{array}$ & $\begin{array}{l}0.13 \\
0.69\end{array}$ & $\begin{array}{l}0.90 \\
0.0001\end{array}$ & $\begin{array}{r}-0.10 \\
10.75\end{array}$ & $\begin{array}{l}0.20 \\
0.53\end{array}$ & $\begin{array}{l}0.32 \\
0.31\end{array}$ & $\begin{array}{l}0.30 \\
0.34\end{array}$ & $\begin{array}{l}0.19 \\
0.55\end{array}$ & $\begin{array}{r}-0.30 \\
0.34\end{array}$ & $\begin{array}{r}-0.34 \\
0.28\end{array}$ \\
\hline BRCHA & & & $\begin{array}{r}-0.21 \\
0.50\end{array}$ & $\begin{array}{l}0.17 \\
0.60\end{array}$ & $\begin{array}{l}0.92 \\
0.0001\end{array}$ & $\begin{array}{r}-0.08 \\
10.81\end{array}$ & $\begin{array}{l}0.14 \\
0.66\end{array}$ & $\begin{array}{l}0.26 \\
0.41\end{array}$ & $\begin{array}{l}0.35 \\
0.26\end{array}$ & $\begin{array}{l}0.31 \\
0.33\end{array}$ & $\begin{array}{r}-0.29 \\
0.36\end{array}$ & $\begin{array}{r}-0.19 \\
0.55\end{array}$ \\
\hline BDENS & & & & $\begin{array}{l}0.71 \\
0.01\end{array}$ & $\begin{array}{r}-0.33 \\
0.30\end{array}$ & $\begin{array}{l}0.12 \\
0.70\end{array}$ & $\begin{array}{r}-0.16 \\
0.62\end{array}$ & $\begin{array}{l}0.14 \\
0.66\end{array}$ & $\begin{array}{r}-0.52 \\
0.08\end{array}$ & $\begin{array}{r}-0.06 \\
0.85\end{array}$ & $\begin{array}{r}-0.32 \\
0.30\end{array}$ & $\begin{array}{r}-0.20 \\
0.54\end{array}$ \\
\hline BDENA & & & & & $\begin{array}{l}0.01 \\
0.97\end{array}$ & $\begin{array}{r}-0.13 \\
0.68\end{array}$ & $\begin{array}{r}-0.09 \\
0.78\end{array}$ & $\begin{array}{r}-0.17 \\
0.59\end{array}$ & $\begin{array}{r}-0.14 \\
0.66\end{array}$ & $\begin{array}{l}0.26 \\
0.42\end{array}$ & $\begin{array}{r}-0.11 \\
0.74\end{array}$ & $\begin{array}{r}-0.14 \\
0.66\end{array}$ \\
\hline AREA & & & & & & $\begin{array}{r}-0.24 \\
0.46\end{array}$ & $\begin{array}{l}0.37 \\
0.24\end{array}$ & $\begin{array}{l}0.34 \\
0.28\end{array}$ & $\begin{array}{l}0.36 \\
0.25\end{array}$ & $\begin{array}{l}0.24 \\
0.45\end{array}$ & $\begin{array}{r}-0.23 \\
0.46\end{array}$ & $\begin{array}{r}-0.11 \\
0.73\end{array}$ \\
\hline SHDV & & & & & & & $\begin{array}{r}-0.26 \\
0.41\end{array}$ & $\begin{array}{l}0.05 \\
0.87\end{array}$ & $\begin{array}{l}0.16 \\
0.62\end{array}$ & $\begin{array}{r}-0.23 \\
0.47\end{array}$ & $\begin{array}{r}-0.26 \\
0.42\end{array}$ & $\begin{array}{l}0.10 \\
0.75\end{array}$ \\
\hline TDEN & & & & & & & & $\begin{array}{l}0.49 \\
0.11\end{array}$ & $\begin{array}{r}-0.11 \\
0.74\end{array}$ & $\begin{array}{r}-0.06 \\
0.85\end{array}$ & $\begin{array}{l}0.07 \\
0.82\end{array}$ & $\begin{array}{r}-0.49 \\
0.11\end{array}$ \\
\hline DDEN & & & & & & & & & $\begin{array}{r}-0.45 \\
0.14\end{array}$ & $\begin{array}{l}0.22 \\
0.49\end{array}$ & $\begin{array}{r}-0.59 \\
0.04\end{array}$ & $\begin{array}{r}-0.52 \\
0.09\end{array}$ \\
\hline TBAS & & & & & & & & & & $\begin{array}{l}0.01 \\
0.97\end{array}$ & $\begin{array}{l}0.36 \\
0.26\end{array}$ & $\begin{array}{l}0.41 \\
0.18\end{array}$ \\
\hline DBAS & & & & & & & & & & & $\begin{array}{r}-0.51 \\
0.09\end{array}$ & $\begin{array}{r}-0.05 \\
0.88\end{array}$ \\
\hline TDIV & & & & & & & & & & & & $\begin{array}{l}0.13 \\
0.69\end{array}$ \\
\hline
\end{tabular}

\begin{tabular}{lccccccccccccc}
\hline & CCOV & TSCV & MSCV & LSCV & MLCV & TOCV & HECV & WATR & PEAT & TSVL & MLVL & TOVL & FHD \\
\hline BRCHS & 0.11 & -0.26 & 0.50 & 0.48 & 0.58 & 0.43 & 0.07 & -0.56 & -0.06 & -0.13 & 0.46 & 0.22 & 0.20 \\
& 0.73 & 0.42 & 0.10 & 0.11 & 0.05 & 0.17 & 0.83 & 0.06 & 0.84 & 0.68 & 0.13 & 0.48 & 0.54 \\
BRCHA & -0.10 & -0.10 & 0.33 & 0.56 & 0.46 & 0.52 & 0.06 & -0.47 & -0.04 & 0.05 & 0.46 & 0.32 & 0.22 \\
& 0.75 & 0.76 & 0.30 & 0.06 & 0.14 & 0.08 & 0.86 & 0.13 & 0.89 & 0.88 & 0.13 & 0.31 & 0.49 \\
BDENS & 0.18 & -0.28 & 0.33 & -0.10 & 0.25 & -0.13 & -0.43 & 0.03 & 0.61 & -0.07 & -0.08 & -0.09 & -0.50 \\
& 0.58 & 0.38 & 0.30 & 0.75 & 0.44 & 0.70 & 0.16 & 0.94 & 0.03 & 0.83 & 0.82 & 0.79 & 0.10 \\
BDENA & -0.03 & 0.16 & -0.09 & -0.07 & -0.10 & 0.13 & -0.11 & -0.25 & 0.65 & 0.34 & 0.19 & 0.30 & -0.13 \\
& 0.92 & 0.62 & 0.78 & 0.83 & 0.76 & 0.68 & 0.74 & 0.43 & 0.02 & 0.28 & 0.56 & 0.34 & 0.69 \\
\multirow{2}{*}{ AREA } & 0.11 & -0.26 & 0.35 & 0.68 & 0.51 & 0.31 & 0.04 & -0.51 & -0.06 & -0.16 & 0.20 & 0.04 & 0.22 \\
& 0.74 & 0.42 & 0.27 & 0.02 & 0.09 & 0.32 & 0.91 & 0.09 & 0.85 & 0.61 & 0.53 & 0.90 & 0.49 \\
\multirow{2}{*}{ SHDV } & -0.44 & 0.23 & 0.03 & -0.19 & -0.04 & 0.36 & -0.02 & 0.05 & -0.07 & 0.20 & 0.49 & 0.42 & 0.07 \\
& 0.15 & 0.46 & 0.94 & 0.55 & 0.91 & 0.25 & 0.96 & 0.87 & 0.83 & 0.53 & 0.11 & 0.18 & 0.82 \\
TDEN & 0.50 & -0.33 & -0.004 & 0.30 & 0.09 & -0.46 & -0.005 & -0.05 & -0.11 & -0.25 & -0.29 & -0.32 & 0.07 \\
& 0.10 & 0.29 & 0.99 & 0.34 & 0.78 & 0.13 & 0.99 & 0.88 & 0.74 & 0.44 & 0.36 & 0.31 & 0.83
\end{tabular}


Appendix E. (concluded)

\begin{tabular}{|c|c|c|c|c|c|c|c|c|c|c|c|c|c|}
\hline & $\mathrm{CCOV}$ & $\operatorname{TSCV}$ & MSCV & LSCV & MLCV & TOCV & HECV & WATR & PEAT & TSVL & MLVL & TOVL & FHD \\
\hline \multirow[t]{2}{*}{ DDEN } & 0.06 & -0.65 & 0.47 & 0.52 & 0.56 & -0.31 & -0.34 & 0.31 & -0.03 & -0.49 & -0.25 & -0.42 & -0.33 \\
\hline & 0.85 & 0.02 & 0.12 & 0.08 & 0.06 & 0.33 & 0.27 & 0.32 & 0.94 & 0.11 & 0.43 & 0.17 & 0.30 \\
\hline \multirow[t]{2}{*}{ TBAS } & -0.23 & 0.27 & -0.23 & 0.11 & -0.16 & 0.23 & 0.50 & -0.60 & -0.15 & -0.03 & 0.40 & 0.24 & 0.70 \\
\hline & 0.48 & 0.40 & 0.48 & 0.74 & 0.62 & 0.47 & 0.10 & 0.04 & 0.63 & 0.93 & 0.20 & 0.46 & 0.01 \\
\hline \multirow[t]{2}{*}{ DBAS } & -0.48 & 0.06 & -0.19 & 0.09 & -0.13 & -0.10 & -0.09 & 0.12 & 0.37 & 0.08 & 0.09 & 0.10 & -0.14 \\
\hline & 0.12 & 0.87 & 0.56 & 0.77 & 0.68 & 0.75 & 0.79 & 0.71 & 0.23 & 0.81 & 0.79 & 0.77 & 0.66 \\
\hline \multirow[t]{2}{*}{ TDIV } & 0.14 & 0.33 & -0.46 & -0.21 & -0.46 & -0.11 & 0.41 & -0.01 & -0.24 & 0.11 & -0.11 & -0.02 & 0.43 \\
\hline & 0.66 & 0.29 & 0.13 & 0.51 & 0.13 & 0.74 & 0.19 & 0.97 & 0.45 & 0.74 & 0.72 & 0.96 & 0.17 \\
\hline \multirow[t]{2}{*}{ THGT } & -0.25 & 0.23 & -0.25 & 0.17 & -0.16 & 0.17 & 0.03 & -0.16 & 0.02 & 0.10 & -0.23 & -0.10 & 0.16 \\
\hline & 0.43 & 0.47 & 0.43 & 0.60 & 0.61 & 0.61 & 0.94 & 0.62 & 0.95 & 0.76 & 0.47 & 0.77 & 0.62 \\
\hline \multirow{2}{*}{$\mathrm{CCOV}$} & & -0.56 & 0.48 & 0.05 & 0.43 & -0.34 & -0.19 & -0.33 & -0.01 & -0.43 & -0.34 & -0.45 & -0.19 \\
\hline & & 0.06 & 0.12 & 0.88 & 0.17 & 0.27 & 0.56 & 0.29 & 0.98 & 0.16 & 0.28 & 0.14 & 0.56 \\
\hline \multirow[t]{2}{*}{ TSCV } & & & -0.78 & -0.53 & -0.83 & 0.52 & 0.50 & -0.01 & -0.15 & 0.87 & 0.47 & 0.77 & 0.43 \\
\hline & & & 0.003 & 0.08 & 0.0008 & 80.08 & 0.10 & 0.99 & 0.64 & 0.0002 & 20.12 & 0.004 & 0.16 \\
\hline \multirow[t]{2}{*}{ MSCV } & & & & 0.32 & 0.96 & 0.07 & -0.55 & -0.17 & 0.16 & -0.57 & 0.04 & -0.28 & -0.49 \\
\hline & & & & 0.31 & 0.0001 & 10.83 & 0.06 & 0.61 & 0.62 & 0.05 & 0.89 & 0.38 & 0.11 \\
\hline \multirow[t]{2}{*}{ LSCV } & & & & & 0.59 & -0.05 & -0.15 & -0.15 & -0.11 & -0.39 & -0.40 & -0.46 & 0.07 \\
\hline & & & & & 0.05 & 0.88 & 0.63 & 0.65 & 0.74 & 0.20 & 0.20 & 0.13 & 0.82 \\
\hline \multirow[t]{2}{*}{ MLCV } & & & & & & 0.04 & -0.52 & -0.19 & 0.10 & -0.61 & -0.09 & -0.38 & -0.39 \\
\hline & & & & & & 0.89 & 0.08 & 0.56 & 0.75 & 0.03 & 0.79 & 0.22 & 0.20 \\
\hline \multirow[t]{2}{*}{ TOCV } & & & & & & & 0.11 & -0.30 & -0.12 & 0.63 & 0.71 & 0.79 & 0.17 \\
\hline & . & & & & & & 0.74 & 0.35 & 0.72 & 0.03 & 0.01 & 0.002 & 0.59 \\
\hline \multirow[t]{2}{*}{ HECV } & & & & & & & & -0.42 & -0.63 & 0.19 & 0.21 & 0.23 & 0.94 \\
\hline & & & & & & & & 0.18 & 0.03 & 0.56 & 0.52 & 0.47 & 0.00 \\
\hline \multirow[t]{2}{*}{ WATR } & & & & & & & & & 0.05 & 0.07 & -0.34 & -0.18 & -0.54 \\
\hline & & & & & & & & & 0. & 0.84 & 0.28 & 0.58 & 0.07 \\
\hline \multirow[t]{2}{*}{ PEAT } & & & & & & & & & & -0.04 & 0.04 & 0.01 & -0.62 \\
\hline & & & & & & & & & & 0.91 & 0.89 & 0.98 & 0.03 \\
\hline \multirow[t]{2}{*}{ TSVL } & & & & & & & & & & & 0.45 & 0.82 & 0.14 \\
\hline & & & & & & & & & & & 0.14 & 0.001 & 0.66 \\
\hline \multirow[t]{2}{*}{ MLVL } & & & & & & & & & & & & 0.88 & 0.22 \\
\hline & & & & & & & & & & & & 0.0002 & 20.49 \\
\hline \multirow[t]{2}{*}{ TOVL } & & & & & & & & & & & & & 0.22 \\
\hline & & & & & & & & & & & & & 0.50 \\
\hline
\end{tabular}

apper number is Pearson correlation coefficient, Lower number is significance of correlation. 
Appendix F. Variable codes.

\begin{tabular}{ll}
\hline Code & \multicolumn{1}{c}{ variable } \\
\hline BRCHS & Species richness of singing birds \\
BRCHA & Species richness of all birds observed \\
BDENS & Relative abundance of singing birds \\
BDENA & Relative abundance of all birds \\
AREA & Area \\
SHDV & Surrounding habitat diversity \\
TDEN & Tree density \\
DDEN & Dead tree density \\
TBAS & Tree basal area \\
DBAS & Dead tree basal area \\
TDIV & Tree species diversity \\
THGT & Tree height \\
CCOV & Tree canopy cover \\
TSCV & Tall shrub cover \\
MSCV & Medium shrub cover \\
LSCV & Low shrub cover \\
MLCV & Medium and low shrub cover \\
TOCV & Total shrub cover \\
HECV & Herb cover \\
WATR & Surface water cover \\
PEAT & Depth (thickness) of peat \\
TSVI & Tall shrub foliage volume \\
MLVI & Medium and low shrub foliage volume \\
TOVL & Total shrub foliage volume \\
FHD & Foliage height diversity \\
\hline
\end{tabular}




\section{BIBLIOGRAPHY}

A.0.U. 1983. Check-list of North American birds, 6th edition. American Ornithologist's Union, Allen Press, Lawrence, Kansas. $877 \mathrm{pp}$.

Anderson, K.S., and H.K. Maxfield. 1962. Sampling passerine birds in a wooded swamp in southeastern Massachusetts. Wilson Bull. 74:381-385.

August, P.V. 1983. The role of habitat complexity and heterogeneity in structuring tropical mammal communities. Ecology 64:1495-1507.

Beecher, W.J. 1942. Nesting birds and the vegetation substrate. Chicago ornith. Soc., Chicago, Illinois. $69 \mathrm{pp}$.

Best, L.B., and D.F. Stauffer. 1986. Factors confounding evaluation of bird-habitat relationships. Pages 209216 in J. Verner, M.L. Morrison, and C.J. Ralph, eds. Wildlife 2000, modeling habitat relationships of terrestrial vertebrates. Univ. Wisconsin Press, Madison.

Black, I.H., and G.M. Seeley. 1953. Breeding bird census no. 12: wet deciduous forest. Audubon Field Notes 7:340341 .

Blake, J.G., and J.R. Karr. 1987. Breeding birds of isolated woodlots: area and habitat relationships. Ecology $68: 1724-1734$.

Blondel, J., C. Ferry, and B. Frochot. 1981. Point counts with unlimited distance. Pages 414-420 in C.J. Ralph and J.M. Scott, eds. Estimating the numbers of terrestrial birds. Stud. Avian Biol. 6.

Brown, M., and J.J. Dinsmore. 1986. Implications of marsh size and isolation for marsh bird management. J. Wildl. Manage. 50:392-397.

Canfield, R. 1941. Application of the line-interception method in sampling range vegetation. J. Forestry $39: 388-394$.

Clark, K.L., D.L. Euler, and E. Armstrong. 1983. Habitat associations of breeding birds in cottage and natural areas of central ontario. Wilson Bull. 95:77-96. 
Connor, E.F., and E.D. McCoy. 1979. The statistics and biology of the species-area relationship. Am. Nat. $113: 791-833$.

Daubenmire, R.F. 1959. Canopy coverage method of vegetation analysis. Northwest sci. 33:43-64.

DeGraaf, R.M. 1987. Breeding birds and gypsy moth defoliation: short-term responses of species and guilds. Wildl. Soc. Bull. 15:217-221.

Dowdy, S., and S. Wearden. 1983. Statistics for research. John Wiley \& Sons, New York. 537pp.

Edwards, D.K., G.L. Dorsey, and J.A. Crawford. 1981. A comparison of three avian census methods. Pages 170176 in C.J. Ralph and J.M. Scott, eds. Estimating the numbers of terrestrial birds. Stud. Avian Biol. 6 .

Emlen, J.T. 1971. Population densities of birds derived from transect counts. Auk 88:323-342.

Emlen, J.T. 1977. Estimating breeding season bird densities from transect counts. Auk 94:455-468.

Forman, R.T.T., and M. Godron. 1986. Landscape ecology. John Wiley \& Sons, New York. 619pp.

Goldsmith, F.B., C.M. Harrison, and A.J. Morton. 1986. Description and analysis of vegetation. Pages 437-524 in P.D. Moore and S.B. Chapman, eds. Methods in plant ecology, second edition. Blackwell scientific Publications, oxford.

Golet, F.C., A.J.K. Calhoun, D.J. Lowry, W.R. DeRagon, and A.J. Gold, in prep. The ecology of red maple swamps in the glaciated Northeastern United States: a community profile. U.S. Fish Wildl. Serv. Biol. Rep. $90(\ldots)$.

Golet, F.C., and A.F. Davis. 1982. Inventory and habitat evaluation of the wetlands of Richmond, Rhode Island. Occas. Pap. Environ. Sci: No. 1. Univ. Rhode Island, Kingston. $48 \mathrm{pp}$.

Gotfryd, A., and R.I.C. Hansell. 1986. Prediction of bird community metrics in urban woodlots. Pages $321-326$ in J. Verner, M.L. Morrison, and C.J. Ralph, eds. Wildlife 2000: modeling habitat relationships of terrestrial vertebrates. Univ. Wisconsin Press, Madison.

Gottfried, B.M. 1979. Small mammal populations in woodlot islands. Am. Midl. Nat. 102:105-112. 
James, F.C., and N.O. Wamer. 1982. Relationships between temperate forest bird communities and vegetation structure. Ecology 63:159-171.

Karr, J.R. 1981. Surveying birds with mist nets. Pages 62-67 in C.J. Ralph and J.M. Scott, eds. Estimating the numbers of terrestrial birds. Stud. Avian Biol. 6.

Kroodsma, R.L. 1984. Effect of edge on breeding forest bird species. Wilson Bull. 96:426-436.

Lack, D. 1942. Ecological features of bird faunas of small British islands. J. Anim. Ecol. 11:9-36.

Linehan, J.T., R.E. Jones, and J.R. Longcore. 1967. Breeding bird populations in Delaware's urban woodlots. Audubon Field Notes 21:641-646.

Lynch, J.F., and D.F. Whigham. 1984. Effects of forest fragmentation on breeding bird communities in Maryland, USA. Biol. Conserv. 28:287-324.

MacArthur, R.H. 1964. Environmental factors affecting bird species diversity. Am. Nat. 98:387-397.

MacArthur, R.H., and J.W. MacArthur. 1961. On bird species diversity. Ecology 42:594-598.

MacArthur, R.H., and E.O. Wilson. 1967. The theory of island biogeography. Princeton Univ. Press, Princeton, New Jersey. 203pp.

Martin, T.E. 1980. Diversity and abundance of spring migratory birds using habitat islands on the Great Plains. Condor 82:430-439.

Martin, T.E. 1988. Habitat and area effects on forest bird assemblages: is nest predation an influence? Ecology $69: 74-84$.

Meyers, P.N., T.W. Gutzke, and H.P. Laskowski. 1981. Breeding bird census no. 6: red maple-pin oak-mixed hardwoods. Am. Birds 35:51.

Morrison, M.L., I.C. Timossi, and K.A. With. 1987. Development and testing of linear regression models predicting bird-habitat relationships. J. Wildl. Manage. 51:247-253.

N.O.A.A. 1989. New England climatic data annual summary. Nat. Climatic Data Center, Asheville, North Carolina. 
oelke, H. 1966. 35 years of breeding-bird census work in Europe. Audubon Field Notes 20:635-642.

opdam, P., G. Rijsdijk, and F. Hustings. 1985. Bird communities in small woods in an agricultural landscape: effects of area and isolation. Biol. conserv. 34:333-352.

Peitzmeier, J. 1950. Untersuchengen uber die siedlungsdichte der Vogelwelt in kleinen Geholzen in Westfalen. Nat. Heimat 10:30-37.

Preston, F.W. 1960. Time and space and the variation of species. Ecology 41:611-627.

Preston, F.W. 1962. The ecological distribution of commonness and rarity. Ecology 43:185-215, 410-432.

Rector, D. 1981. Soil Survey of Rhode Island. U.S. Dept. Agric., Soil Conserv. Serv., West Warwick, Rhode Island.

Robbins, C.S., D.K. Dawson, and B.A. Dowell. 1989. Habitat area requirements of breeding forest birds of the Middle Atlantic States. Wildl. Monogr. 103:1-34.

Seeley, G.M. 1954. Breeding bird census no. 6: wet deciduous forest. Audubon Field Notes $8: 366$.

Seeley, G.M. 1955. Breeding bird census no. 3: wet deciduous forest. Audubon Field Notes 9:412-413.

Seeley, G.M. 1956. Breeding bird census no. 3: wet deciduous forest. Audubon Field Notes 10:420.

Seeley, G.M. 1957. Breeding bird census no. 1: wet deciduous forest. Audubon Field Notes 11:436.

Seeley, G.M. 1966. Breeding bird census no. 2: wet deciduous forest. Audubon Field Notes 20:608.

Shannon, C.E. 1948. The mathematical theory of communication. Pages 3-91 in C.E. Shannon and Weaver, eds. The mathematical theory of communication. Univ. Illinois Press, Urbana.

Simberloff, D. 1972. Models in biogeography. Pages 160-191 in T.J.M. Schopf, ed. Models in paleobiology. Freeman, San Francisco, California.

Simberloff, D. 1976. Experimental zoogeography of islands: effects of island size. Ecology 57:629-648. 
Simberloff, D., and L.G. Abele. 1982. Refuge design and island biogeographic theory: effects of fragmentation.

Am. Nat. 120:41-50.

Slack, R.S., P.G. Valka, V.J. Lucid, and J. McMullen. 1975. Breeding bird census no. 3: red maple forest. Am. Birds 29:1082-1083.

Swift, B.L. 1980. Breeding bird habitats in forested wetlands of west-central Massachusetts. M.S. Thesis, Univ. Massachusetts, Amherst. 90pp.

Swift, B.L., J.S. Larson, and R.M. DeGraaf. 1984 . Relationship of breeding bird density and diversity to habitat variables in forested wetlands. Wilson Bull. $96: 48-59$.

Taylor, G.W. 1984. Breeding bird census no. 3: red maple swamp. Am. Birds 38:69.

Tiner, R.W. 1989. Wetlands of Rhode Island. U.S. Fish Wildl. Serv., Nat. Wetlands Inventory, Newton Corner, Massachusetts. $71 \mathrm{pp}$.

Tyser, R.W. 1983. Species-area relations of cattail marsh avifauna. Passenger Pigeon 45:125-128.

Weller, M.W. 1979. Wetland habitats. Pages 210-234 in P.E. Greeson, J.R. Clark, and J.E. Clark, eds. Wetland functions and values: the state of our understanding. Am. Water Resour. Assoc., Minneapolis, Minnesota.

Whitcomb, R.F., c.S. Robbins, J.F. Lynch, B.L. Whitcomb, M.K. Klimkiewicz, and D. Bystrak. 1981. Effects of forest fragmentation on avifauna of the eastern deciduous forest. Pages 125-206 in R.L. Burgess and B.M. Sharpe, eds. Forest island dynamics in man-dominated landscapes. Springer-Verlag, New York.

Widoff, L. 1988. Maine wetlands conservation priority plan. Maine Bur. Parks Recreation, state Planning office, Augusta. $91 \mathrm{pp}$.

Wright, W.R., and Sautter, E.H. 1988. Soils of Rhode Island landscapes. Univ. Rhode Island Agric. Exp. Sta. Bull. 429 , Kingston. 42 pp. 